\title{
Ocidente e história em Golbery do Couto e Silva
}

Vânia Noeli Ferreira de Assunção ${ }^{1}$

\section{Resumo:}

Este texto tem por objeto a visão de Ocidente presente no pensamento do general Golbery do Couto e Silva, explicitado em suas obras Geopolítica do Brasil e Planejamento estratégico. Para analisá-la, aborda-se sua visão de homem, de história, de estado e de civilização; traz-se à luz a sua inspiração teórica para o debate sobre civilização ocidental e encerra-se com a relação de dependência mútua que percebe entre Brasil e Ocidente, além das proposições que faz a partir desse diagnóstico, da opção pelo Ocidente e da criação do Brasil-potência.

Palavras-chave: Golbery do Couto e Silva; civilização ocidental; pensamento conservador.

\section{The West and History in Golbery do Couto e Silva}

\begin{abstract}
:
This text has as its object the vision of the West present in the thinking of General Golbery do Couto e Silva, explained in his works Geopolitics of Brazil and Strategic planning. To analyze it, it approaches his vision of man, history, state and civilization; and its theoretical inspiration is brought to light for the debate on civilization, ending with the relationship of mutual dependence that he perceives between Brazil and the Western civilization, besides the propositions that he makes from this diagnosis, the option for the West and the creation of Brazil-power.
\end{abstract}

Key words: Golbery do Couto e Silva; western civilization; Conservative thinking.

O general Golbery do Couto e Silva (1911-87) foi uma das principais personagens da história brasileira da segunda metade do século XX. Unia as qualidades de intelectual e homem prático a serviço da burguesia, à qual foi útil em várias ocasiões². Buscamos deixar claro, em outro momento,

${ }^{1}$ Doutora, professora da Universidade Federal Fluminense (UFF - Rio das Ostras) e editora-chefe da Verinotio. E-mail: vanianoeli@uol.com.br. Agradeço a Ester Vaisman pelos argutos comentários.

${ }^{2}$ Foi o responsável pela escrita do Memorial dos coronéis, que resultou no afastamento do então ministro do Trabalho, João Goulart, em 1954; propôs a redução dos poderes presidenciais como "solução" para a crise resultante da renúncia de Jânio Quadros à 
que o ideário golberyano estava voltado "à interferência prática na realidade, na tentativa de solucionar em determinado sentido os conflitos que ali se davam", ou seja, tinha "uma função social inegável: mantenedora de uma formação social de molde colonial, embora tecnicamente avançada” (ASSUNÇÃO, 1999, p. 223). Ele não pretendeu uma neutralidade e nem a achava possível, num mundo travejado por um antagonismo que marcava com seu selo todos os assuntos importantes, interna e externamente aos estados nacionais. Se, comparado com sua importância histórica, durante muito tempo seu pensamento foi negligenciado, atualmente, já há algumas pesquisas que buscaram compreender, com graus diversos de profundidade, amplitude (e sucesso), sua teoria ${ }^{3}$.

Este texto se propõe a discutir sua noção de Ocidente, central para a caracterização que ele faz das alianças que o Brasil deveria celebrar em um mundo convulsionado pela guerra fria; e do apoio que o país deveria receber por sua colaboração na defesa do mundo cristão "ocidental e democrático" contra o comunismo "materialista”, “alienígena" e "totalitário". Por meio da análise imanente dos textos do autor, iniciamos abordando alguns conceitos básicos do seu pensamento (como homem, história e estado). Expomos, em largos traços, as elaborações de Oswald Spengler e Arnold Toynbee sobre a civilização ocidental, as quais influenciaram fortemente o pensamento golberyano no tocante, especificamente, ao tema em tela neste artigo. Em seguida, focamos especificamente na visão do general a respeito do Ocidente: suas características gerais e sua situação atual. Terminamos abordando a forma como o autor tenta resolver a contradição entre uma proposta nacionalista e a opção pelo Ocidente.

Presidência, em 1961; foi criador e gestor do Serviço Nacional de Informações (SNI), em 1964; e ministro da Casa Civil dos governos dos presidentes-ditadores Ernesto Geisel e João Batista Figueiredo, dos quais era apontado como eminência parda, para ficar em apenas alguns exemplos (cf. GASPARI, 2003).

3 Entre os pioneiros na análise de seu pensamento estão Schilling (1981), com a teoria do subimperialismo brasileiro; Covre (1983), que abordou Golbery do Couto e Silva juntamente com outros representantes da tecnocracia da ditadura; e Ferreira (1984) e Mello (1997), que discutiram a sua contribuição para a geopolítica. A atuação prática do general foi objeto de pesquisa de Gaspari (2003), depositário de seus documentos pessoais. No nosso trabalho anterior (ASSUNÇÃO, 1999), expusemos os nódulos centrais do seu pensamento, tendo como mote a noção de bonapartismo e a oposição entre segurança e desenvolvimento. Uma síntese competente apareceu posteriormente em Birkner (2002). Carvalho (2010) é um ótimo trabalho sobre a problemática das relações internacionais no pensamento de general aqui sob escrutínio, muito embora sob outra perspectiva teórica. Já a dissertação de Nascimento (2013), no nosso entender, sem prejuízo de alguns acertos, carece de rigor teórico, retrocede ao igualar o pensamento da ESG ao do general aqui em pauta e, ademais, assume posicionamentos ideologicamente conservadores. 


\section{Homem, história e dialética: alguns apontamentos sobre as bases do pensamento golberyano}

Para entendermos a visão de civilização ocidental ou Ocidente no pensamento golberyano, optamos por recuar um pouco e começar buscando sua visão de ser humano e sua visão de história, para depois acompanharmos seu raciocínio em relação à formação da dita civilização. Como buscaremos explicitar, seu pensamento é eclético, um mixto compositum que incorpora com maior ou menor sucesso elementos contraditórios entre si.

É o caso da dialética, formalmente integrada ao seu pensamento que, no entanto, mantém dicotomias e determinismos totalmente antidialéticos. Assim, apesar das raízes profundamente positivistas do exército brasileiro, instituição à qual ele próprio não só estava ligado como era umas expressões mais bem-formadas, Silva recorria à dialética - arquiinimiga do positivismo - em suas tematizações. Embora sem nenhuma formulação mais aprofundada ou sequer uma conceituação precisa, ele destacou a dialética - a contradição imanente e o devir constante a todos os processos, coisas e relações - enquanto forma da história, inerente ao próprio real: "as contradições, ao revés, antes difusas e apagadas, aos poucos se individualizam melhor e acabam por polarizar-se, (...) gerando tensões internas que mais ou menos se avolumam até que, por um impulso dialético, se produza afinal a síntese libertadora que inaugurará novo ciclo de evolução" (SILVA, 1981a, p. 21). Ou, ainda: “Todo conflito pressupõe, assim, uma semelhança entre contrários, tanto quanto, no justo pensar de Heráclito, é o verdadeiro demiurgo da realidade mutável de nosso eterno devir." (SILVA, 1981b, p. 16) Por constatar a mutabilidade do real, considerava fundamental apelar a uma visão dialética, "Marx excluso se quiserem" (SILVA, 1981b, p. 479): se a dialética é parte da realidade, é imprescindível que seja capturada pelo pensamento (SILVA, 1981b, pp. 22-3). Isso, como já se pode ver na citação anterior, não equivale a estar associado a uma visão de esquerda: "Eu não sou, estou longe de ser, esquerdista, mas acho que as contradições são, até certo ponto, o 'sal da vida', porque elas obrigam a buscar a solução aos problemas" (SILVA, 1981b, p. 507).

Numa visão que se queria, portanto, dialética, sua teoria captava o homem como "ente social ou político" (SILVA, 1981a, p. 95), “animal social", "membro nato e obrigatório de uma sociedade mais ou menos dilatada, mais ou menos complexa, mais ou menos solidária” (SILVA, 1981a, p. 9). Donde, "O contato, mais ou menos estreito, mais ou menos duradouro, condiciona sempre, a rigor, todo e qualquer processo de interação social, quer entre indivíduos, quer mesmo entre grupos" (SILVA, 
1981a, p. 200). O autor estava, assim, longe das visões liberais que remetem ao indivíduo atomizado ou isolado como origem de uma sociedade artificial criada posteriormente.

Tal característica antropológica se intensificaria no decorrer da sua história, já que a "integração é um processo social, permanente e dinâmico, que apresenta fases críticas de retrocesso e fases positivas de recuperação mais ou menos acelerada, mas desconhece a estagnação duradoura" (SILVA, 1981a, p. 169). Este animal gregário, desde logo social, teria sua inserção na sociedade mediada pelos diversos círculos intermediários dos quais participa:

\begin{abstract}
Partícipe, ao mesmo tempo, de múltiplos e variadíssimos grupos sociais mais ou menos amplos e inclusivos, mais ou menos absorventes e dinâmicos, dotados de um maior ou menor grau de pressão e de controle sociais, dose maior ou menor de estabilidade e permanência, especialização funcional mais ou menos rígida, grupos primários e grupos secundários, privados ou públicos, disjuntivos ou não, tanto horizontais como verticais, tanto profanos como sacros, simples ou complexos, naturais e inalienáveis ou de associação livre e voluntária (...) - a cada um desses conjuntos, liga-o relação de dependência mais ou menos estreita, a traduzir-se, em termos de uma adesão mais ou menos consciente, por um coeficiente de lealdade extremamente variável. (SILVA, 1981a, pp. 95-6)
\end{abstract}

Vê-se, pois, que o general, mantendo-se longe do atomismo, mas também do materialismo, não localizava no âmbito da produção e reprodução da vida os elementos que unem os homens, deixando aberta a questão do que subjaz aos diversos círculos aos quais devem "distintas lealdades".

Segundo o autor, as relações sociais em épocas remotas exigiriam lealdade suprema ao "grupo mais restrito - a família, o clã, a própria tribo", havendo ainda muitas sobrevivências desta orientação. Citando Vico, Danilewski, Spengler e Toynbee, afirmava que a história humana se trataria "do alargamento paulatino do próprio âmbito em que acaba por manifestar-se, até certo ponto inconteste, essa sua lealdade suprema”, história que passaria por "sucessivos ciclos de evolução, correspondentes a expansões e contrações desse mesmo círculo da lealdade maior do homem, nas várias áreas ecumênicas que este, sob seu domínio, vitalizou" (SILVA, 1981a, p. 97). É o jeito de o autor retratar abstratamente o processo de constituição da humanidade enquanto gênero.

Esse processo, afirmava, não ocorreria de maneira linear e evolucionista, mas conheceria diversos conflitos. No seu entender, o animal social que é o homem "foi e sempre será o polo de uma hierarquia de lealdades - frequentes vezes, palco íntimo de dilaceradores conflitos entre lealdades diferentes", as quais seriam em diversas ocasiões parcial ou 
totalmente inconciliáveis, "por mais que seu antagonismo possa subsistir largo tempo despercebido e larvado, antes de explodir, destroçador e pungente, nos decisivos momentos de uma crise de opção", sendo a fonte de tragédias e neuroses a tentativa de conciliá-las: "Não obedecerás senão a um único senhor teu deus - eis, pois, o supremo mandamento social” (SILVA, 1981a, pp. 95-6). Há aí uma tensão constante, porque, "se o contato intenso favorece (...) a amizade e a colaboração internacionais, essas só se vêm, em geral, a concretizar após um período (...) de conflitos e choques, de lutas ostensivas e surdas pela hegemonia, (...) processo através do qual se acabe por atingir uma situação de estabilidade mais durável e profícua” (SILVA, 1981a, p. 173). A constituição histórica da humanidade implicaria, assim, conflitos íntimos dos indivíduos em relação às instituições às quais deveriam lealdade, bem como conflitos objetivos entre os diversos agrupamentos humanos que se aproximariam no decorrer da história. Trata-se de uma socialidade inerentemente conflituosa.

Assim, o referido caráter gregário inerente à natureza do homem estaria acompanhado de um egoísmo e de um egocentrismo também imanentes, no entender do general. Seria, portanto, "O homem integrante da sociedade, com todas as suas naturais motivações de lucro, de bemestar, de afirmação do seu ego, de sede de aplausos e de prestígio, de solidariedade social e humana também" (SILVA, 1981b, p. 408). Este homem egoísta estaria em constante conflito com o mundo circundante. Por isso seria acossado pelo medo, um estado de espírito terrível decorrente da "insegurança eterna do homem" diante de um mundo que não compreendia e onde lutava para sobreviver - o "aturdimento profundo do espírito humano ante o mundo complexo e insondável que o circunda e por vezes o sufoca e até mesmo o agride” (SILVA, 1981b, p. 11). Assim, o general mesclava correntes teóricas distintas para, com base numa visão de homem como animal social, afirmar o seu egoísmo imanente, bem de acordo com sua percepção de que o contato embute conflitos constantes.

Juntamente com a socialidade e a integração, o egoísmo e o medo decorrente da insegurança, a liberdade também faria parte da natureza humana, constituiria um "valor eterno, pois que verdadeiro padrão de humanidade" (SILVA, 1981b, p. 410). Mas a afirmação abstrata é, em seguida, relativizada: no decorrer da história, acossado pelo "medo cósmico" e a fim de obter segurança, a humanidade teria engendrado o estado, ao qual teria delegado um "poder soberano, incontrastável e supremo" (SILVA, 1981b, p. 361).

Embora tenha deixado algumas indicações no decorrer dos escritos, Silva não ofereceu uma definição inequívoca, didática, de estado - um 
conceito muito importante em seu pensamento ${ }^{4}$. Nessas diversas menções sobre constituição e desenvolvimento do estado, recorria frequentemente às metáforas biológicas típicas do organicismo: o estado tem "vida", é "organismo" social ou político e outras. Como quer se defina, o importante é salientar que, para ele, desde que surgiu o estado seria o agente no cenário internacional e também no interno, caráter ativo que lhe caberia pelo fato de ser representante dos objetivos nacionais. O estado como instituição neutra, mediador e cimento social, é o que se pode peneirar de seus comentários a respeito, que desconsideravam as contradições internas no grupo social organizado sob um estado. Esse "novo Leviatã, esse deus portentoso, embora mortal, da soberania e do poder absoluto", à qual a sociedade delegara poderes excepcionais, fora descoberto por Hobbes e apontado como criação racional de uma sociedade atormentada pela insegurança, o que a teria levado a trocar sua autonomia e sua liberdade individuais pela segurança, a garantia de sobrevivência. Muito embora criticasse eventuais "utilizações incorretas" da teoria hobbesiana pelos déspotas, minorias tirânicas e novos césares, o autor em pauta não questionava seus fundamentos, pelo contrário, reafirmava-a continuamente.

Continuando seu raciocínio, ele criticava o liberalismo, que teria tornado o estado tornado inerte, amorfo e anêmico, e, por isso, assombrado pelos imensos perigos inerentes à própria vida humana, o homem estaria preso em um "dilema eterno" que o obrigaria a escolher recorrentemente entre a liberdade e a segurança. Essa dicotomia liberdade/segurança é significativa para seu raciocínio e será inclusive elevada a slogan institucional do período bonapartista inaugurado em 1964, com participação ativa de Golbery do Couto e Silva. Mesclam-se aqui elementos de Hobbes, Locke e Spengler para formar o quadro das duras escolhas a que seria obrigado o homem contemporâneo - e, assim, das justificativas para opções antitéticas às características atribuídas à sua natureza.

Como Silva caracterizava os agrupamentos humanos e sua evolução histórica? O autor, recusando o que entendia por monocausalidade linear, afirmava a existência de estruturas parciais em constante interação e das quais algumas teriam capacidade de determinação sobre outras, formando “estruturas dinâmicas em perpétua evolução”. Ele tomava a esfera moral5

4 Ele chegou a afirmar, em entrevista: "Os povos são um mito: só existem as nações, e a nação é o estado" (OESP, 6-8-76). Uma contradição com a ideia das culturas que se encarnam em povos, engendradas justamente para suplantar o estado-nação como unidade de análise.

5 Nessa questão da importância da moral para a cimentação social, percebe-se uma semelhança com Durkheim (cf. CARLI, 2017). Essa semelhança também aparece em relação à ideia durkehimiana de solidariedade mecânica e orgânica (cf. DURKHEIM, 2007) e a golberyana de escala de lealdades, bem como na noção de morfologia, Essa 
como aquela dominante, com maior poder de arrastamento e maior autonomia, como os valores religiosos na Idade Média. No seu entender, em cada época haveria uma "intermediável evolução da civilização e da cultura, eterna floração de valores novos por sobre um vasto estendal de valores ultrapassados e mortos" (SILVA, 1981b, p. 375). Em cada "etapa do desenvolvimento estrutural", haveria "uma hierarquia de instituições, de estruturas parciais", levando ao destaque de valores peculiares, dessa pletora de valores novos, os quais ganhariam predominância, teriam "poder de arrastamento quase que irresistível, motivando repercussões das mais imprevistas nos setores mais distantes e diferenciados" e que teriam "uma autonomia maior, um grau de liberdade muito superior, uma menor plasticidade às influências alheias" (SILVA, 1981b, p. 89).

Para Silva, "desde o albor mesmo de sua humanidade", o homem teria criado "novos mundos à medida de seus desejos mais íntimos e na razão de sua perspicácia cada vez mais aguçada”. Assim, quaisquer que fossem os modelos ou estruturas conceituais existentes, tanto os eleitos pelo pensamento científico quanto os estéticos ou os religiosos, seriam "modelos, sempre simplificados embora", de uma realidade complexa que "se esquiva e se opõe à sua decifração total", "tentativas mais ou menos bem-sucedidas, mais ou menos fracassadas, de reduzir a multidimensionalidade complexa do mundo à escala simplificada do homem" (SILVA, 1981b, pp. 12; 14).

Numa interpretação culturalista - que, portanto, desconsiderava a centralidade da produção da vida -, citava os modelos mágico, antigo, ordenado/místico, meio-panglossiano e pessimista. Assim, acreditava, "toda a história da cultura da humanidade" seria "um suceder caleidoscópico desses mundos-modelos que, em cada época, traduzem a perspectiva sempre cambiante do mundo aos olhos sempre cambiantes do homem" (SILVA, 1981b, p. 12).

Modelos parciais, deformados por uma perspectiva unilateral e simplista do enigma da existência e da vida e muitas vezes edificados sobre a crença vã em uma monocausalidade reveladora que tudo explique, (...) conseguem por vezes polarizar a ânsia eterna de inteligibilidade perfeita que impulsiona o espírito humano no descobrimento do mundo, mas (...) não muito tempo resistem ao rude confronto com a realidade irredutível. (SILVA, 1981b, p. 14)

A busca por se aproximar do conhecimento exato do real pelo "método seguro e cauteloso das aproximações sucessivas" (SILVA, 1981b, p. 259), que poderia ser saudável se contextualizasse as determinações sociais para a ciência e a razão, era em seu pensamento (mal) amalgamada

aproximação com Durkheim se deu, possivelmente, via Spengler, que teria sofrido influência do sociólogo francês (SILVA, 2008, pp. 38ss). 
com uma forte influência do irracionalismo de Spengler6, citado insistentemente. É assim que, ao discutir a necessidade de planejamento, ele salientava:

\begin{abstract}
o conhecimento do "mundo-como-natureza", esquematizado em leis, fórmulas, teorias e sistemas que a ciência friamente investiga e elabora no plano da causalidade, se demonstrará de todo insuficiente estéril se não dispusermos, ao mesmo tempo, de uma interpretação viva do momento que passa, à luz de uma perspectiva fisiognômica do passado - o conhecimento -, muito mais intuitivo que racionalista, do "mundo-como-processohistórico" (SILVA, 1981b, p. 163).
\end{abstract}

Para encerrar esse panorama sobre sua visão de homem, para o autor em tela, não seriam todos os homens os artífices da própria história. $\mathrm{Na}$ verdade, em vários momentos dava a entender que os homens são mobilizados por forças que estão acima e além deles, manipulando-os a seu bel-prazer, e ele não hesitava em chamá-las de "um destino condicionador de todas as atividades humanas". na esteira de Spengler (SILVA, 1981b, p. 163). Note-se que a contradição entre essa visão e a sua defesa enfática da dialética não é enfrentada em nenhum momento.

De outro lado, as decisões que valem seriam tomadas por um grupo seleto, as minorias criadoras. No coração da geopolítica e da estratégia propostas por Silva estava a noção de objetivos nacionais, que seriam a tradução dos interesses e aspirações do grupo nacional, assentadas na preservação da nação enquanto tal, asseguradas as condições de autodeterminação, integração crescente, prosperidade, bem-estar e prestígio (cf. SILVA, 1981b, p. 60 e passim). Mas os objetivos nacionais e aspirações não estariam grafados explicitamente na sociabilidade, necessitando de uma interpretação e uma formulação mais precisa, objetiva e contextualizada, uma "obra política de sábia auscultação e interpretação legítima do sentir e pensar de todo um povo" (SILVA, 1981a, pp. 101-2). Essa reelaboração, "instinta e resulta naturalmente do processo histórico através do qual o grupo adquire e plasma uma consciência nacional" (SILVA, 1981b, p. 60), seria responsabilidade das elites, por serem "grupos mais densos e superiormente equipados em poderio e cultura" (SILVA, 1981a, p. 98).

\footnotetext{
${ }^{6}$ De acordo com Lukács, o irracionalismo é uma tendência filosófica que "convierte los límites del conocimiento intelectivo, petrificándolos, en límites del conocimiento en general, e incluso mistifica el problema, convertido aí, artificiosamente, en insoluble, haciendo de él una solución 'suprarracional" (LUKÁCS, 1972, p. 77). Desta maneira, torna em uma situação insuperável a incapacidade ou limitação de certos conceitos em captar a realidade - que ocorre em momentos de grandes transformações sociais e crises - , hipostasiada ao ponto de aparecer como limite do próprio conhecimento racional, o qual se propõe substituir por algum tipo de intuição irracional, tida como superior. Enquanto tal, é recente e representa uma forma de reação ao desenvolvimento dialético do pensamento humano que ocorre nos marcos da produção capitalista e das suas lutas de classes próprias (cf. LUKÁCS, 1972, pp. 75-103).
} 
Apelando aqui também para um elemento presente na tradição conservadora brasileira, o autor em pauta acreditava que os atores da história são as classes dominantes - ou, melhor dizendo, os estratos dirigentes das classes dominantes, que ele denominava de "elite". Nesse ponto, além da herança do conservadorismo, ele também sofria influência do pensamento de Spengler e Toynbee e acabava vendo a política como um fenômeno quase autônomo, no qual o povo "não é sujeito da história da Nação (...) é tão-só o objeto da ação estatal destinada a erguer, na dignidade e no realismo crítico, a grandeza do Brasil” (FERREIRA, 1984, p. 597).

Mais que auscultar instintivamente os anseios da alma nacional, caberia às elites incuti-los nas massas deles inconscientes, completando-se a interpretação com "uma ampla tarefa educativa, também, que cumpre às verdadeiras elites representativas realizar" (SILVA, 1981a, pp. 101-2). A tarefa de reconhecê-los, traduzi-los e anunciá-los como guias da ação política seria tanto mais importante quanto menos a nação estivesse consciente deles, destacando-se aí a capacidade criativa das elites no captá-los ainda imberbes, dar-lhes conteúdo coerente e mais rico e educativamente inculcá-los no povo, "como que em promissora autofecundação”, "catequizá-lo e mobilizá-lo ao pragmatismo e dinamismo da ação efetiva” (SILVA, 1981b, p. 458). Por outros termos, a capacidade da chamada elite dirigente de "sensibilizar e atrair a massa, em arrastá-la docilmente sob sua liderança eficaz pela força carismática que desperte e assegure o mecanismo mimético que Toynbee tão bem descreveu, dá bem a medida real de seu poder criador" (SILVA, 1981b, p. 366).

Ressalte-se que tais tarefas só poderiam ser cumpridas pelas "verdadeiras elites representativas", também elas parte do povo, com o qual dividiriam objetivos a ser atingidos caso cada uma das forças sociais, elite e massa, cumprisse suas funções - diferentes mas complementares, como na tradição do pensamento organicista. Só assim se poderia atingir uma condição harmônica que o autor denominava - novamente tratando a história como algo transcendental - como "épocas conscientes", as que enfrentam desafios pelos esforços conjugados das elites e das massas, com essas sendo arrastadas, com sua "adesão voluntária e consciente", pela "liderança esclarecida das minorias dirigentes", "com o mínimo de atritos e o máximo de coerência e de objetividade (SILVA, 1981a, pp. 375; 419, grifos nossos).

Passada sob os nossos olhos a noção golberyana de ser humano e de sua história, é a hora de abordarmos sua visão de civilização humana. 


\section{Civilização ocidental: características e estatuto atual}

A noção de preeminência do Ocidente em face de outros povos é antiquíssima, mas tomou ares de superioridade absoluta, progressiva e irreversível em relação a todos os povos anteriores e posteriores ao final do século XVIII, com a ascensão política da burguesia. As conquistas tecnológicas e científicas seriam o atestado de que apenas o Ocidente poderia receber o desígnio de civilização, "pois foi só entre os povos do Ocidente cristão que a religião, a arte e o ‘saber desinteressado’ da ciência gozaram de maior favorecimento, com exceção de períodos relativamente breves" (ABBAGNANO, 2007, p. 143). Para Silva, fazia pouco tempo que esse "quase tradicional conceito otimista" de "progresso continuamente ascendente" da humanidade fora "ultrapassado por uma concepção muito mais realista e menos estultamente orgulhosa - a da pluralidade de culturas", que teria o caráter de uma verdadeira revolução copernicana (SILVA, 1981b, p. 165). A Ilustração teria redundado, no seu entender, "num cientificismo resseco e sem alma" que só graças aos progressos técnicos manteve, por algum tempo, a ilusão de marcha ascensorial da civilização ocidental - bem como teriam multiplicado o potencial destrutivo das guerras e da decadência do Ocidente (SILVA, 1981b, p. 166).

Em algumas ocasiões (cf. 1981b pp. 165ss), o ensaísta sintetizou a "monumental doutrina vitalista de Spengler", defendendo-a de algumas críticas, bem como apontando as semelhanças e diferenças com o raciocínio de Toynbee. É necessário, então, fazer uma pequena pausa e expor, em linhas muito gerais, sem nenhuma pretensão de esgotar sua compreensão, de alguns elementos do pensamento de ambos mais atinentes ao nosso autor. Enfatizamos que escapa ao nosso objetivo fazer uma análise comparativa entre eles, pois pretendemos apenas chamar a atenção para as dívidas intelectuais confessadas pelo general.

\section{As fontes teóricas de Golbery do Couto e Silva quanto ao entendimento de Ocidente e civilização ocidental}

O alemão Oswald Spengler sofreu influências tão díspares quanto de Leibniz, Goethe, Durkheim e Nietzsche e, por sua vez, influenciou de Arnold Toynbee a Ortega y Gasset. Lançou o primeiro tomo de sua obra mais célebre, $A$ decadência do Ocidente, em 1918. Havia na Alemanha um debate acerca das noções de cultura e de civilização, debate que passava pela própria definição do que seria o Ocidente, em termos políticoculturais e geográficos. No bojo dessa discussão, os próprios termos utilizados foram também objeto de disputa. Assim, enquanto na Alemanha a palavra Abendland (Ocidente) era de uso mais comum nos meios 
conservadores e religiosos, o termo "Europa" era utilizado por liberais e socialistas. Spengler tomou partido pela eliminação da noção de Europa, substituindo-a por outra, a seu ver mais pertinente, a de Ocidente: "O termo 'Europa' deveria ser eliminado da história. Não existe nenhum tipo histórico de 'europeu' (...). O Oriente e o Ocidente são conceitos de genuíno teor histórico. A 'Europa' é um termo totalmente vazio." (SPENGLER, 1973, p. 34)

Imiscuindo-se no debate historiográfico de sua época, Spengler criticava o caráter eurocêntrico da história tradicional, que arrogantemente se autointitulava "universal":

O território da Europa ocidental constitui o polo imóvel - não se sabe por que, a não ser pela razão de que nós, os realizadores desse quadro histórico, nascemos justamente neste lugar. Ao redor do mencionado o polo, giram, com toda a modéstia, milênios de história, sumamente importantes (...). Escolhe-se uma determinada região, para que sirva de centro natural de um sistema histórico. Representando o sol, de onde os acontecimentos históricos recebem uma iluminação autêntica, determina ela a perspectiva sobre a qual é medida a importância de tudo quanto ocorrer. (SPENGLER, 1973, p. 34)

O autor alemão apelidava o eurocentrismo que identificava na historiografia de "sistema ptolomaico da história", segundo o qual todos os povos girariam em torno da Europa ocidental, em contraposição à qual propunha uma sorte de "revolução copernicana". Partia de Nietzsche, para quem a história era uma narrativa poética e a ambição de torná-la uma ciência seria uma degeneração e uma tentativa de aplicar-lhe a lógica da fábrica, com a pretensão de chegar a uma verdade histórica inexistente. A "revolução copernicana” que Spengler propunha deveria começar com o repúdio à ideia de história como ciência, pois esta seria antes uma arte, revelada não apenas pela razão mas, também, pela intuição, pelas impressões sensíveis, a partir de um método comparativo inspirado no originalmente elaborado por Goethe para as ciências naturais, que consistiria em derivar os fenômenos a partir de um fenômeno primitivo único, método que designava morfologia. A morfologia relativa ao orgânico, à história, à vida, a tudo que seria teleologicamente dirigido ele dava o nome de fisiognomia.

Pensam alguns realizar uma investigação histórica, ao irem em busca do nexo objetivo de causa e efeito. Mas, ao lado do físico e do matemático, o historiador parecerá relaxado, cada vez que passar da coleção e da classificação do material para sua interpretação. Ainda não penetrou nas nossas formulações teóricas a convicção de que, além da necessidade de causa e efeito - e que eu gosto de te chamar de lógica do espaço - há na vida ainda há necessidade orgânica do destino - a lógica do tempo. Esta última constitui um fato de profunda certeza 
íntima; um fato que dá conteúdo a todo o pensamento mitológico, religioso, artístico; um fato que forma o núcleo e a essência de toda a história, em oposição à natureza, mas que permanece inacessível aos métodos de conhecimento [sistemáticos]. (SPENGLER, 1973, p. 27)

Para Spengler, a causalidade, lógica do espaço, ligada à razão, ao intelecto, relacionada aos procedimentos exatos e "mortíferos" da física moderna, estaria em busca de um domínio sistemático das leis naturais e das relações causais. Já o "mundo-enquanto-história", o âmbito do "mover-se e vir a ser", não seria alcançável pela razão, pois seria o campo da intuição, da morfologia do "orgânico", da história e do "destino" e obedeceria à lógica do tempo "A matemática e o conceito da causalidade conduzem a uma ordem naturalista dos fenômenos. A cronologia e a ideia do destino levam a uma ordem histórica. (SPENGLER, 1973, p. 27) Buscar classificar "os acontecimentos políticos espirituais" em categorias causais e acompanhar "tendência aparente, suscetível de ser captada pelo intelecto", "Esse tratamento - "pragmático" - da história não passaria de uma parcela de ciência natural disfarçada" (SPENGLER, 1973, p. 26). A "ordem profunda" da vida só poderia ser "observada e sentida", não explicada nem dirigida racionalmente, pois a compreensão conceitual mede, disseca, "mata" o objeto. "O meio pelo qual reconhecemos as formas mortas é a lei matemática. O meio pelo qual compreendemos as formas vivas é analogia." (SPENGLER, 1973, p. 24) Logo, a fisiognomia seria o método próprio de interpretação da história, que não estaria em busca de causalidade, mas seria necessariamente criador, intuitivo e subjetivo, rechearia de alma e de sentimento o objeto percebido: "Não se trata, pois, daquilo que são os fatos tangíveis da história em si, como fenômenos ocorridos em determinado tempo, mas do que significam, do que indicam por meio da sua aparência." (SPENGLER, 1973, p. 26)

Em suma, o método fisiognômico seria um imperativo epistemológico para compreensão da história, tarefa impossível para os saberes dominantes de sua época, que, por serem racionalistas, não compreenderiam que o "sentido da realidade" só seria apreensível pelo olhar interpretativo do fisiognomista. Nesse mister, em vez de indagar em que medida e como o desenvolvimento histórico-social influi no conhecimento da natureza, seu historicismo absolutizava a relatividade histórica e eliminava o caráter aproximativo do conhecimento da natureza. Sua metodologia, ao partir de "fenômenos primigênios", "proclama la 'fisionomia' de cada cultura como fundamento real de todas sus manifestaciones concretas" intrínsecas ou formais, estruturais ou dinâmicas, e "la construcción científica auxiliar se convierte, así, en un fundamento real, aunque en un fundamento real irracionalista por 
principio y que sólo puede captarse por la vía de la intuición” (LUKÁCS, 1972, p. 380).

Quando abordou o tema da cultura, Spengler o fez no interior do debate intelectual que marcou sua época, entre cultura (Kultur) e civilização (Zivilisation). Ele foi pioneiro ao propugnar uma pluralidade de culturas:

Em lugar da monótona imagem de uma história universal retilínea, deparo com o espetáculo de múltiplas culturas poderosas, a brotarem com cósmico vigor do seio de uma região maternal, à qual todas elas permanecem ligadas, rigorosamente, por todo o curso da sua existência. Cada qual dessas culturas imprime à sua matéria, que é o espírito humano, a sua forma peculiar; cada qual tem suas próprias ideias, suas próprias paixões, sua vida, sua vontade, seu sentir, sua morte próprios. (SPENGLER, 1973, p. 39)

As culturas teriam, para ele, um ciclo vital, passando por etapas, por analogia, "biológicas", da qual a história universal seria a biografia geral. Cada cultura equivaleria a um indivíduo biológico independente da raça que a porta.

\begin{abstract}
Essas culturas, seres vivos de ordem superior (...), fazem parte da natureza viva de Goethe e não da natureza morta de Newton. Enxergo na história universal a imagem de uma eterna formação e transformação, de um maravilhoso desenvolvimento e ocaso de formas orgânicas. (SPENGLER, 1973, p. 40)
\end{abstract}

A etapa que receberia especificamente o nome "cultura" seria a primeira, momento de esplendor, na qual vigeriam a ética, a vida, a criação, a arte, os valores aristocráticos e patriarcais como honra, virilidade, poder, respeito, lealdade, espírito de renúncia; o momento da comunidade harmônica unida por laços estreitos, hierarquia social rígida e clara percepção identitária, com os homens ligados entre si e à terra como uma paisagem cósmica.

A última das etapas do ciclo vital de uma cultura seria justamente a civilização, "Concebida como consequência orgânico-lógica, como remate e término de uma cultura", ou seja, "cada cultura tem a sua própria civilização” (SPENGLER, 1973, p. 46). Dessa forma, civilização está relacionada à expansão, ao utilitarismo, à urbanidade, à petrificação, ao ceticismo, à decrepitude espiritual e à falta de ética, ao declínio e à morte7:

\footnotetext{
7 Ele associava à Alemanha as características da cultura - ética, criatividade, valores tradicionais, comunidade e religiosidade, além de poder centralizado: na Prússia "o poder pertence ao todo. O indivíduo serve a esse todo. A totalidade é soberana" (SPENGLER apud HERF, 1993, p. 65). Era a antítese da Inglaterra e da França, onde vigeriam a anarquia e igualitarismo (nesta última) e a competitividade mercantil (na primeira), resultando numa dispersão do poder, morte, utilitarismo, estagnação, expansionismo caracteres da civilização, em que a alma faustiana esgotada se manifestaria num novo homem individualista, racional, cético, civilizado, com fria mentalidade metropolitana.
} 
"A civilização pura, como processo histórico, consiste na demolição gradual de formas mortas, que já se tornaram e inorgânicas.” (SPENGLER, 1973, p. 47)

Só o método fisiognômico teria o pendor de revelar a certeza ou o "caráter íntimo" das culturas, suas singularidades, suas semelhanças, sua duração e seu término, já que a história seria cíclica: "têm cada cultura, cada época primitiva, cada ascensão, cada decadência, cada qual das suas fases e dos seus períodos intimamente necessários, uma duração fixa, que sempre se repete com a insistência de um símbolo" (SPENGLER apud SILVA, 2008, p. 64). Assim, as culturas teriam todas passado por períodos de nascimento, florescimento e morte - embora haja ambiguidades no tocante à questão da decadência em alguns dos seus textos, com alguma possibilidade de regeneração de uma cultura.

Com isso, o autor acabava desembocando numa análise externa das situações estudadas, no estabelecimento de leis gerais (contrário à ciência da história), num naturalismo e num determinismo que lhe dava até a pretensão de predizer o futuro: "Neste livro acomete-se pela primeira vez a tarefa de predizer a história. Trata-se de visionar o destino de uma cultura, (...) definir o curso que sua evolução tomará nas fases futuras" (SPENGLER, 1973, p. 23). A resultante dessa miscelânea é uma concepção de história que é, a um só tempo, cética, determinista, generalista, esquemática e irracionalista. A história não seria a produção ativa dos seres humanos sob determinadas condições específicas, um certo espaço e um lapso temporal, mas uma situação "natural" cujos ciclos se repetiriam independentemente da ação dos homens. No fim, noções como alma, cultura e destino tomavam o lugar da história enquanto práxis e enquanto ciência, retirando aos próprios homens o controle e o conhecimento racional de sua vida. Nesse mister, a própria noção de gênero humano e de história universal é negada, já que, para ele, não há humanidade, mas blocos culturais orgânicos indivisíveis e incomunicáveis: "A humanidade' é um conceito zoológico ou uma palavra vazia.” (SPENGLER, 1973, p. 39)

Spengler sugeria, como visto, uma interpretação histórica que ressaltava a originalidade de outras civilizações, tornando o atributo "civilização", antes associado apenas ao Ocidente, algo plural, compartilhando em igualdade com outros povos, que teriam atingido realizações igualmente grandiosas. $\mathrm{O}$ autor rejeitava, portanto, a noção de que só o Ocidente teria alcançado o nível de civilização, como era corrente na sua época, visto este nível como o auge da evolução de uma cultura. Mas é forçoso reconhecer, primeiro, que a civilização era justamente a etapa da decadência de uma cultura, ainda que aparentemente fosse o seu momento de auge, o que minimiza bastante a ampliação do epíteto para outros povos. Ademais, a ocidental era, no seu entender, a cultura mais 
poderosa e mais vibrante dentre todas, a "única no nosso planeta a ter alcançado a sua plenitude" (SPENGLER, 1973, p. 23). Quando se debruçava sobre esse multiculturalismo histórico, tinha como uma das suas mais relevantes preocupações compreender o próprio Ocidente, “definir o curso que sua evolução tomará nas fases futuras” (SPENGLER, 1973, p. 23).

Com predileção por sínteses ambiciosas e acríticas, Spengler atacou diretamente a racionalidade e o espírito científicos. Rejeitando a validade geral da explicação causal e a legalidade objetiva do real, como vimos, optou pela analogia, tornou as comparações e os símiles cânones investigativos. Segundo Lukács, a teoria do conhecimento de Spengler "procede de un modo extraordinariamente primitivo, a base de tópicos y de frases. Se limita a aplicar a la historia las viejas antítesis de la filosofía de la vida entre la vida y la muerte, la intuición y la razón, la forma y la ley", que ele transforma em consignas populares graças à simplificação extrema e à opção por paradoxos (LUKÁCS, 1972, p. 375).

As culturas, como mônadas, seriam completamente independentes e, segundo a maior parte dos intérpretes da teoria spengleriana, impermeáveis uma à outra, incomunicáveis entre si, não se compreenderiam e nem se influenciariam - poderiam, no máximo, traduzir em seus próprios termos elementos de outra cultura. Vem desse ceticismo intercultural a crença splengeriana de que o historiador é incapaz de compreender o ethos de outra cultura que não a própria, cabendo-lhe apenas intuitivamente captar a semelhança e as relações entre elas. O irracionalismo de Spengler o levou não só a atribuir às culturas etapas biológicas como até a estrutura psicológica do indivíduo ou intelectual do período imperialista, já que viveriam encerradas em si mesmas, à maneira solipsista. Ao renunciar à possibilidade de compreensão de outras culturas, adotava a tipologia como "el conocimiento supremo, el único conocimiento fundamental de éstas", radicalização que transforma o relativismo em mito (LUKÁCS, 1972, p. 379).

Como não seria possível uma cultura influenciar ou sobrepor-se a outra, a tentativa de copiar elementos de uma cultura estranha só poderia ocorrer em aspectos externos à alma de cada cultura, sendo, portanto, uma pseudomorfose ${ }^{8}$ : uma cultura assumiria a forma de outra sem modificar sua natureza anímica. Dessa maneira, aquelas instituições, concepções ou

8 Outros intérpretes, porém, consideram a intercambialidade intercultural possível e pseudomorfoses seriam apenas casos especiais. "Pseudomorfoses históricas são para mim aqueles casos em que uma velha cultura estranha pesava com tamanha força sobre um país que uma cultura nova, autóctone, não conseguiu respirar e se tornou incapaz não só de desenvolver formas expressivas peculiares e puras, mas também de alcançar a plenitude de sua consciência própria." (SPENGLER apud SILVA, 2008, p. 73) 
expressões que são símbolos da alma de cada cultura seriam ímpares e irrepetíveis, não podendo ser transferidas ou copiadas corretamente por culturas diferentes. Assim, por exemplo, as técnicas desenvolvidas pelos povos seriam distintas por se originarem de anseios e necessidades específicas da "alma” de cada cultura (e não das injunções materiais). Chama a atenção o fato de Spengler não relacionar a técnica e a ciência ocidentais ao capitalismo e sua racionalidade específica, e sim à intuição e à vontade, forças dotadas de aspectos rituais e místicos semelhantes aos da religião que teriam levado a alma faustiana a se espalhar por diversos espaços naturais. Naquele momento já avançado da objetivação do capitalismo, à tecnologia e à ciência são atribuídos caracteres mitológicos e de reencantamento do mundo, numa forma de proceder "típica da aceitação e da rejeição seletiva das modernidades capitalistas" (HERF, 1993, p. 69). Trata-se de uma clara opção teórica instrumental: a era imperialista não podia ser totalmente reacionária e propugnar o retorno ao primitivo e ao bucólico; portanto, não podia prescindir da tecnologia, o que levou diversos intelectuais do período a incorporá-la à Kultur alemã enquanto uma força aparentemente autônoma em relação às relações sociais nas quais surgiu, negando-lhe racionalidade e associando-a à metafísica e ao misticismo irracionais e românticos. Spengler podia, assim, ser simultaneamente anticapitalista e defensor da tecnologia e da industrialização.

Lembre-se de que, para o autor, os "povos de cor" (principalmente os russos e os orientais) poderiam tomar de empréstimo os métodos, os usos e os resultados das ciências próprias da alma fáustica e, como para eles elas não constituíam uma necessidade da alma, poderiam ser manipuladas e instrumentalizá-las. Ele criticava o Ocidente por não guardar seu maior tesouro, a técnica, mas antes exportá-la para todo o mundo, dada a prevalência da alma faustiana. Sua incorporação pelos "povos de cor" representaria grande perigo para a civilização ocidental, pois terminariam por utilizar-se delas contra o próprio Ocidente em sua "revolução mundial", tornando a expansão da cultura fáustica, a maior grandeza do Ocidente, simultaneamente em sua maior fraqueza, que poderia dar vez à ascensão de outra civilização. Assim, o tema da decadência e da transformação da cultura em civilização se completava com a transferência da preeminência política e cultural de um povo para outro.

Spengler queixava-se de que a esfera da circulação, "parasitária” e "saqueadora", houvesse se sobreposto à indústria e à agricultura, a economia produtiva, da qual a tecnologia era vista como parte inseparável. A especulação e a busca de lucros é que depauperariam o poder dos produtores e consumidores e a mercantilização da vida social se deveria ao 
dinheiro e aos tipos individuais que seriam seus condutores (como o mercador), não às relações sociais capitalistas. Contribuía, assim, na busca pela "conciliação de sentimentos românticos e irracionalistas com o entusiasmo pelo avanço técnico", acreditando "que essa crise cultural pudesse ser 'superada' por meio da mobilização nacionalista” (HERF, 1993, pp. 63-4). Adotando a tecnologia como parte da "alma" alemã, incorporava consequentemente a indústria num anticapitalismo romântico bastante peculiar no qual a preservação do "sangue e da tradição" exigiria os mais modernos recursos tecnológicos, sendo necessário à aristocracia dominá-los incondicionalmente, mantendo-se longe do perigo de se tornar conservadora no que toca aos meios (HERF, 1993, p. 72). Era, pois, um anticapitalismo que não questionava em nenhum momento as relações de classe e de propriedade - embora criticasse o dinheiro, visto como força destrutiva - e, assim, uma teoria bastante útil para diversos fins políticomilitares e econômicos da época.

Spengler radicalizou e deu conteúdo mais abrangente à ideia nietzschiana de decadência da civilização ocidental, palpável na ciência, na arte, na política e na cultura. A decadência da civilização ocidental arrastaria consigo os demais povos, com os quais tinha contato e preponderância. Esgotada em seu potencial criador, com alma envelhecida, tendo já atingido a plenitude no desenvolvimento de seus valores morais e expressões intelectuais e artísticas, ela assumiria então, necessariamente, a forma de cesarismo:

Le nouveau parlementarisme va représenter la lutte pour la vie, sous des formes beaucoup moins maitrisées et avec beaucoup plus d'insuccès. Le rapport des leaders au parti et du parti aux masses sera plus brutal, plus transparente, sans fard. C'est le début du césarisme. (...) Nous non plus, nous ne lui échapperons pas longtemps. $C^{\prime}$ est là notre destin, comme ce fut celui des Romains, des Chinois, de toutes les civilisations parvenues à maturité. Mais connaîtrons-nous le césarisme des milliardaires ou des généraux, des banquiers ou des fonctionnaires de stature exceptionnelle? C'est là l'éternelle question. (SPENGLER apud GOMES, 2013, p. 131)

Cesarismo seria a espécie de governo que estaria desprovida de forma em sua natureza íntima, em que as instituições políticas estariam mortas, apesar das formas de direito público aparentemente conservadas, e a única que permaneceria com significado seria o poder pessoal exercido pelo césar. Seria um tipo de organização estatal autocrática que "quebrará a ditadura do dinheiro e a respectiva arma política: a democracia”, configurando- na saída para a crise cultural advinda de "um suposto excesso de abstração e intelecto” (HERF, 1993, pp. 76-7). Ou, como sintetizou o próprio Spengler, "É o retorno de um mundo, que atingiu a 
sua forma, ao primitivo, ao que é cosmicamente anistórico" (SPENGLER apud GOMES, 2013, p. 53).

Outro autor que influenciou direta e fortemente o pensamento golberyano no tocante ao tema do Ocidente foi Arnold Toynbee, professor e diplomata inglês. Sua principal obra, em 12 tomos, é Um estudo da história, publicada a partir dos anos 1930. Toynbee era crítico da velha história política de fundamentos nacionalistas - atribuía, inclusive, ao sentimento nacionalista os massacres perpetrados na I Guerra Mundial -, por entender impossível a compreensão da história universal nos marcos inflexíveis dos estados-nação. Avaliava que estes fariam parte de um todo maior, a civilização, e que a história desta seria a única válida, sendo necessário, então, partir do todo para depois chegar às histórias particularizadas de seus povos e nações. De outra parte, também rejeitava a história monográfica, hiperespecializada, que ele associava à predominância do modo de pensamento introduzido pelas sociedades industriais e suas linhas de montagem, uma "perversão inerente à sociedade industrial", um "estreitamento de horizontes" (TOYNBEE apud BARROS, 2009, p. 224). Registre-se, ademais, que era um radical inimigo das explicações baseadas na produção material e nos conflitos de classes, ao que voltaremos.

Toynbee questionava a tese de que em sua época haveria uma única civilização, erro a que induziria a ampliação do sistema econômico ocidental ao nível mundial, bem como a difusão de seu modelo político. Entretanto, salientava, em campos distintos das técnicas materiais estéticos, culturais, morais, religiosos etc. - o mundo continuava como era antes da Revolução Industrial inglesa, com as quatro civilizações não ocidentais vivas mantendo claramente seus sinais identitários distintivos.

Como em Spengler, civilização era, para ele, um estágio superior que uma cultura teria atingido no decorrer de seu desenvolvimento ou, ainda: "Se uma cultura pode ser entendida (...) como a 'resposta' dada por um grupo de homens ao 'desafio' representado pelas condições da realidade biológica física e social em que se encontram, pode-se dizer que uma 'civilização' é o conjunto de armas que uma cultura forja para enfrentar o 'desafio"' (ABBAGNANO, 2007 p. 143). Toynbee afirmava a existência de um número incontável de sociedades ou culturas - que ele chamava de "primitivas", sem acepção negativa, já que tinham suas instituições, leis etc., constituindo mundos culturais com algum grau de autonomia. Dessas, 21 haviam conseguido tornar-se civilizações, o que só teria ocorrido em um período muito recente em termos históricos (cerca de seis mil anos atrás), do que concluiu que a maior parte da história humana ocorreu à parte dos processos civilizacionais. Segundo o historiador britânico, daquela vintena de civilizações, muitas haviam 
desaparecido, como a maia, a inca, a mexicana, a egípcia e a índica. Entre as seis que ainda subsistiriam em sua época estariam a hindu, a arábica, a do Extremo Oriente (dividida em os ramos japonês e chinês), a cristã ortodoxa e a ocidental, todas de terceira geração, ou seja, "netas" de civilizações originais, já que as civilizações poderiam "procriar" e deixar descendência. Mas o fato de estas estarem então vivas não significava que não viessem também a colapsar: podiam não ter apenas vivido o suficiente para tanto. Além de serem em número muito maior e constituídas por uma quantidade menor (que, no entanto, poderia chegar a algumas centenas de milhares) de indivíduos, as sociedades primitivas se diferenciariam das civilizações porque teriam uma extensão geográfica menor, uma vida mais breve e nelas as mudanças ocorreriam em velocidade muito inferior à das civilizações; porque estariam mais preocupadas com o passado, enquanto estas mirariam o futuro; e seriam muito menos complexas do que as civilizações. Ele salientava, ademais, que uma civilização não era uma unidade política, mas um coletivo de unidades políticas - as quais ele designava "estados paroquiais" - que compartilhariam de uma mesma cultura ou "estilo" (DRAKE, 2019).

Seu método de estudo, à semelhança de Spengler, era o comparativo, com base em analogias que iluminassem as mais diversas civilizações espalhadas no tempo e no espaço e a busca de leis gerais. Sua principal divergência era a rejeição do determinismo pessimista do "ciclo vital” que o alemão apresentava.

Para Toynbee, mesmo considerando a existência de elementos comuns na evolução das civilizações, a história não seria nunca determinista, com a interveniência da liberdade humana podendo mudar o rumo de uma tendência. Assim, para ele, se as civilizações são passíveis de morte, haveria também a possibilidade de sua sobrevivência. Esta seria possível por um mecanismo de desafio-e-resposta: de tempos em tempos, as sociedades se veriam diante de um desafio de cuja resposta dependeria sua condição posterior, fosse ela o enfraquecimento ou o fortalecimento. Muito mais importante do que a resposta propriamente dita aos desafios encontrados, para ele a questão seria a forma como se responderia, que dependeria de um fator $\mathrm{X}$ de natureza misteriosa (correlacionada à liberdade humana), complexa e dependente de diversas variáveis, além de ter origem interna ou externa. A respostas de cada civilização a um problema, únicas, configurariam o estilo dessa civilização. Cada incitação respondida de forma exitosa traria em seu bojo o gérmen de uma nova incitação produzida pela mesma força que a teria levado ao êxito. $O$ mecanismo funcionava constantemente: para ele, a estagnação significaria a morte e nesse mister a guerra também seria elemento importante para despertar os homens da letargia. 
Note-se que Toynbee desprezava progressos técnicos e materiais como elementos importantes para a explicação dos estágios das culturas e civilizações. "El progreso material, el dominio de las tecnologías, la acumulación de capital tenían en su opinión una importancia secundaria para explicar el auge o colapso de las civilizaciones." (LUZÓN, 2013, p. 54) Criticava as tendências materialistas, segundo as quais o aperfeiçoamento da técnica material é o indicador de correspondentes progressos civilizatórios representados por uma sucessão de "idades" caracterizadas justamente por epítetos ligados às técnicas: idade da pedra, do ferro, da máquina. Tal classificação:

Es sospechosa, en primer lugar, porque apela a los preconceptos de una sociedad que está fascinada por sus propios triunfos técnicos recientes. Otra razón para considerar con sospecha la clasificación tecnológica es la de que constituye un ejemplo manifiesto de la tendencia del estudioso a convertirse en esclavo de los materiales particulares de estudio que el azar ha puesto en sus manos. Desde el punto de vista científico es un mero accidente el que los instrumentos materiales que el hombre "prehistórico" se haya confeccionado hayan sobrevivido, mientras que han perecido sus creaciones psíquicas, sus instituciones e ideas. (TOYNBEE apud LUZÓN, 2013, p. 59)

Para ele, o critério para diferenciar os estágios das culturas e civilizações seria a sua capacidade de autodeterminação:

El crecimiento significa que la personalidad o la civilización en crecimiento tiende a convertirse en su propio contorno y en su propia incitación y en su propio campo de acción. En otras palabras, el criterio de crecimiento es el progreso hacia la autodeterminación; y el progreso hacia la autodeterminación es una fórmula prosaica de describir el milagro por el cual la Vida entra en su Reino. (LUZÓN, 2013, p. 55)

O historiador inglês ainda chamava a atenção para a importância dos grupos dirigentes na condução do conjunto da sociedade, já que, no seu entender, as respostas aos desafios não viriam da sociedade como um todo, mas de um indivíduo ("gênio criador") ou de um pequeno grupo de indivíduos ("minoria criadora"). Esses agentes responsáveis pelas respostas exitosas e inovadoras teriam de ser capazes de arrastar consigo todo o corpo social da civilização.

Este arrastre se produce como en capas concéntricas en las que las capas más interiores captan la esencia de la respuesta y la siguen con convencimiento y entusiasmo. Pero a medida que nos alejamos del centro de la respuesta dada por la minoría creadora, es más bien por una especie de mímesis (...) o imitación más o menos refleja por lo que se sigue la respuesta. (DRAKE, 2019) 
Segundo acreditava, pelo processo de mimese os indivíduos moldariam seu comportamento e seu modo de vida àqueles dos indivíduos ou grupos de referência. Um dos elementos que distinguiriam as sociedades primitivas das civilizações seria justamente a forma como esta mimese aconteceria.

En las primeras la mimesis se dirige hacia la generación más vieja y hacia los antecesores muertos, en consecuencia son estáticas, conservadoras, escasamente creativas, mientras que en las segundas los referentes son las minorías innovadoras y como consecuencia las civilizaciones son dinámicas, liberales y creativas. (LUZÓN, 2013, p. 54)

Para Toynbee, as minorias criadoras não teriam consciência do seu papel histórico e só raramente agiriam para salvar a civilização. Por trás de suas respostas haveria, não raro, uma motivação de caráter místico: “el impulso interno del genio creador que, tras un retiro del mundo para entenderse a sí mismo, retorna para empezar a formar la minoría creadora" (DRAKE, 2019). Após encontrar as respostas adequadas a uma dada incitação, essa minoria costumaria se tornar conservadora, agarrando-se àquela resposta e tornando-se obstáculo à busca de solução para o próximo desafio.

Para Toynbee, os sinais de crescimento de uma civilização não seriam nem a expansão geográfica, nem o poderio militar e nem o desenvolvimento técnico, mas algo que ele chamava de "simplificação progressiva" ou "eterealização", de que a criação artística seria o melhor exemplo. Tratar-se-ia de um processo que:

libera fuerzas que están presas en un medio más material y, por tanto, ponerlas en libertad supone no sólo una simplificación del aparato, sino una transferencia subsiguiente de energía o cambio o acento desde una esfera inferior del ser o de la acción a una superior (DRAKE, 2019).

Se a civilização fracassasse em encontrar a resposta mais adequada aos desafios, ingressaria no que Toynbee chamava de "tempos revoltos". No seu entender, este seria um momento de lutas internas entre distintos aspirantes a dar a resposta a uma incitação, caracterizando-se por grande instabilidade, mas que também carregaria esperança de regeneração. Se se prolongasse muito, porém, haveria a possibilidade de um estado paroquial assestar o golpe de misericórdia nessa civilização, o que o autor designava “tentação suicida do militarismo”. Então, de uma só vez ou aos poucos, dar-se-ia o colapso da referida civilização, após o qual uma minoria se tornaria dominante e, para preservar seu domínio, imporia à força a unidade política à civilização, o “estado universal”. Os demais membros da civilização, segregados daquela minoria, constituiriam o "proletariado interno", uma confusa massa sem mais traços comuns que o ser excluída das decisões políticas e, em geral, economicamente deserdada. Os 
bárbaros de fora da civilização seriam o "proletariado externo", os quais admirariam a civilização e desejariam integrar-se a ela antes do colapso, mas agora ansiariam por dominá-la. A partir desse momento, ocorreria a desintegração da civilização.

O estado universal poderia ter duração multissecular e alcançar inclusive grandes êxitos militares, econômicos e institucionais, além de trazer sensação de estabilidade e segurança. Inobstante, o estilo daquela civilização iria sendo corroído paulatinamente pelas dissensões entre a minoria dominante e o proletariado interno, o que provocaria uma dissociação desta civilização da alma de seus habitantes. Bem assim, o proletariado externo a iria pressionando e minando suas bases. Ambas as situações à levariam à desintegração, mesmo que houvesse possibilidades de regeneração (nunca realizadas na história).

Ao cisma no corpo social, entre minoria dominante, proletariado interno e proletariado externo, Toynbee ajuntava ainda o que chamava de "cisma na alma", que afetaria - de formas distintas - tanto os membros da minoria dominante quanto o proletariado interno. Entre as diversas reações possíveis nas condutas, modos de vida e sentimentos dos membros de uma civilização colapsada, individual e coletivamente, estariam a transfiguração e o sentido de unidade. Estas gerariam na alma de algumas pessoas da civilização colapsada uma necessidade de transcendência que, por sua vez, poderia engendrar uma religião superior. Esta poderia encarnar, caso o processo se completasse, em uma sociedade de novo tipo, designada por ele de "igreja universal”. A aparição dessas igrejas universais ou religiões superiores seria justamente a finalidade da história, numa noção que junta ao misticismo a visão teleológica.

Apresentados os traços principais da teoria do historiador inglês, fica evidente porque, para Lukács, em relação ao que fora produzido por Spengler, as novidades apresentadas por Toynbee eram apenas pontuais ou secundárias:

Toynbee es, em todos los problemas fundamentales, un simple epígono del epígono de la filosofía de la vida, de Spengler. Todas sus concepciones esenciales: su actitud en contra de la unidad de la historia, la equiparación valorativa de todas las civilizaciones, la explicación del progreso como una ilusión etc., están tomadas de aquél. (LUKÁCS, 1972, p. 656)

Para o filósofo húngaro, não se pode atribuir propriamente originalidade ao número de "ciclos naturais" construídos mais ou menos arbitrariamente por um ou outro autor. Não é também exatamente um avanço o fato de que Toynbee não trabalhasse com o irracionalismo biológico de Spengler, pois este era substituído por "símiles puramente mitológicos" que pretendem descrever "el puro milagro irracional que supone el paso histórico de una cultura del estado estático al estado 
dinâmico" (LUKÁCS, 1972, p. 656). Ademais, o historiador embasava toda a sua filosofia da história no cristianismo, no qual encontrava a saída para a crise em que a sociedade ocidental estaria envolta, além de elaborar teoricamente o elitismo presente na sociedade de sua época.

Além de Spengler e Toynbee, o conceito golberyano de Ocidente também seria devedor da geopolítica - como a de Halford Mackinder, que ressaltava a oposição entre oceanismo e continentalismo; e a de Rudolf Kjellén, para quem algumas condições geopolíticas (como espaço e posição) seriam determinantes para a preeminência no âmbito das relações internacionais. Bem assim, também seria caudatária da tradição do pensamento conservador brasileiro. Neste estava presente a evocação a uma "tradição cristã ocidental" ainda herdada de Portugal, vinculando o país à tradição formada desde fins da Antiguidade e que colocava a Igreja Católica como guardiã da cultura ocidental (NASCIMENTO, 2013, p. 65ss.

\section{A perspectiva golberyana: o Ocidente como ideal, propósito e programa}

É tarefa complicada, admitia Silva, caracterizar o que venha a ser a civilização ocidental, e exemplificava com as diferentes visões de diversos autores sobre o tema (com destaque para Spengler e Toynbee). Ao longo do evolver histórico desta civilização, era perceptível, ressaltava, uma variedade grande de "formas, de estruturas, de valores, de ideais e princípios, entre uma dada fase e outro período qualquer" - "do atomismo feudal para o liberalismo citadino ou a férrea centralização cesarista”, por exemplo (SILVA, 1981a, p. 222).

Não seria, contudo, esse Ocidente milenar, "prenhe de tantas antigas tradições", "sobrecarregado de um passado nunca morto de inúmeras aventuras abortadas e de sonhos e ideais fenecidos, onde se defrontam e por vezes guerreiam-se, nas artes, na religião, na filosofia e na ciência, tantos pontos de vista diversos, tantas crenças antagônicas, tantos sistemas opostos", que ele abordaria (SILVA, 1981a, p. 225). Ao mesmo tempo, não seria também o Ocidente atual, no qual impressionaria a qualquer observador "a multiplicidade de estilos de vida, de formas de pensamento, de valores e crenças, criando esse colorido aspecto da 'multanimidade"' - afora a incorporação de traços exóticos propiciada numa era de encontro entre civilizações diferentes (SILVA, 1981a, p. 222). Dessa forma, a ocidental não era uma cultura padronizada. Longe de uma sociedade harmônica e homogênea, o mundo ocidental teria sido repleno de dissensões e agitado por correntes diversas de ideias, de interesses, de crenças, que se digladiariam em todos os setores da vida social, hoje como ontem. 
O Ocidente também não era apontado como o celeiro das virtudes. O general não deixava de mencionar, ainda que apenas muito de passagem, aspectos desabonadores, como "a dominância exercida, em largo período histórico bem recente, pela motivação econômica”, a qual, por "suas exigências particulares - e sem dúvida mesquinhas -", subordinaria toda sabedoria e toda imaginação, desorganizaria a família tradicional, distorceria os preceitos religiosos e imporia o cataclismo da guerra (SILVA, 1981b, p. 90). Por conseguinte, o Ocidente não estava isento de máculas, inclusive "em nome daquele ideal, se têm perpetrado crimes e realizado espoliações e fundado mesmo tiranias” (SILVA, 1981a, p. 225).

Inobstante a diversidade, as dissensões e os equívocos e/ou mesmo crimes, asseverava convictamente Silva, "a cultura ou civilização do Ocidente, tal como a conhecemos afinal, plenamente evoluída e consciente, não se poderia confundi-la nem com qualquer das civilizações que já desapareceram nem com alguma outra das que lhe são contemporâneas" (SILVA, 1981a, p. 221). Ele esclarecia, então, a que Ocidente se referia:

o único Ocidente que vale como um todo duradouro e coeso, o Ocidente que se pode de fato distinguir, nitidamente, de tantas civilizações e culturas, dotado de uma individualidade própria, original e marcadamente característica, é para nós o Ocidente como ideal, o Ocidente como propósito, o Ocidente como programa (SILVA, 1981a, p. 225).

Percebe-se, aqui, um afastamento de toda a teorização de Spengler e Toynbee, sobre as quais o autor edificou seu raciocínio, em nome de uma percepção mistificada de Ocidente e a indistinção quanto a se tratar de uma cultura ou civilização, o que não é posto em dúvida pelos autores que o influenciaram - o Ocidente estaria na fase da civilização. Ainda, trata-se de uma visão idealizada, na qual, curiosamente, o que distinguiria o Ocidente é algo que não existe, de fato, enquanto tal - num autor se reivindicava realista.

O propósito, o ideal, o programa do Ocidente seriam, afirmava o gaúcho, "a ciência, como instrumento de ação", "a democracia - como fórmula de organização política" e "o cristianismo - como supremo padrão ético de convivência social”. Estariam contidos nesses princípios essenciais, segundo o autor esguiano, e "em seus justos limites, liberdade, igualdade, fraternidade; o amplo reconhecimento da dignidade do homem; a plena expansão da personalidade individual; o máximo de bem-estar, físico e espiritual, para todos; a justiça social e a paz" (SILVA, 1981a, p. 226).

Silva afirmava que democracia e ciência não seriam caracteres de fases ou atestado de decadência da civilização ocidental, como em Spengler e Toynbee, mas constituiriam em característica intrínseca ao Ocidente, 
pelo menos enquanto idealização. Isso porque, mesmo quando tomadas de forma extremamente abstratas, tais caraterísticas não eram generalizáveis à cultura ocidental (em sentido spengleriano) efetivamente existente nem no tempo nem no espaço. Tomando-se a história, a democracia não tem sido a regra, por exemplo, na América Latina e mesmo na Europa foi derrotada diversas vezes, algumas delas em período muito próximo ao da escrita dos textos golberyanos (para não falarmos em períodos históricos anteriores, como o feudal). Pegando um outro exemplo ainda relativo à democracia, nos cursos da Escola Superior de Guerra, ela nunca foi colocada como um objetivo nacional atual (de prazo curto ou médio), embora sempre no rol dos objetivos nacionais permanentes: parecia ser um horizonte desejável, mas não ainda realizável, na sociedade brasileira de então. Ele próprio assegurou, como veremos, que a democracia precisava se renovar para se manter - aparentemente, uma mudança sem transformação, já que sem democracia o Ocidente perderia uma de suas características básicas ${ }^{9}$. E nem adentramos no debate sobre os limites da própria democracia e dos direitos humanos, que nos levaria demasiadamente longe dos nossos objetivos aqui.

O cristianismo de que falava o general também comportava diversas diferenças no interior do próprio Ocidente, especialmente se decomposto em catolicismo e protestantismo. A Noite de São Bartolomeu, a Revolução Puritana inglesa e a Inquisição são apenas dois exemplos de lutas umbilicais do próprio cristianismo, cuja identidade histórica não foi sempre idêntica a si mesma.

A questão da ciência chama ainda mais a atenção. Toynbee a atribuía, como a técnica, a um dado período histórico - o da civilização -, e não à fase de cultura, inclusive a rejeitava como padrão para aquilatar o desenvolvimento de uma cultura. Já Spengler, nos mesmos moldes de outros representantes do romantismo de aço modernista reacionário (HERF, 1993), incorporou ideologicamente a técnica à cultura alemã, apartando-a da noção de ciência e racionalidade e aproximando-a da de

\footnotetext{
9 "Para Golbery, o fator essencial que está ligado à democracia não é a defesa das liberdades, embora isso seja fundamental. Para ele, o essencial é a própria participação. (...) Esse fator, participação, é que dá legitimidade e força para o estado tomar uma série de decisões, às vezes contrárias aos interesses imediatos de quem decide. Pode-se dizer que a democracia por ele proposta é uma democracia metodológica ou procedimental, no sentido de que não importa muito o que é decidido, mas como isso é feito. Por isso, ao contrário da estratégia - cuja base são antagonismos e antagonistas -, quem domina esse campo é a política, a arte do possível (...). A democracia participativa golberyana difere essencialmente da democracia participativa reivindicada por movimentos sociais e autores ligados à esquerda, pois, além de instrumental, é essencialmente uma democracia partidária. (...) Canalizar qualquer participação para o âmbito partidário é, pois, concentrá-la aos limites estabelecidos pelo próprio sistema, e que, portanto, não peitaria sua própria fundamentação.” (ASSUNÇÃO, 1999, p. 75)
} 
sangue e tradição. Silva, ao largo desse debate, qualificava a ciência como um dos pilares do Ocidente, novamente desconsiderando todo o período histórico em que a religião constituía o valor proeminente - mais ainda: colocou ciência e cristianismo convivendo pacificamente no interior de sua definição idealizada de Ocidente. Por fim, dissociou-a do capitalismo, chão histórico em que se desenvolveu, tomando-a abstratamente como um guia atemporal.

Interessa ressaltar, como observou Nascimento, que tal formulação "cria um abismo entre a teoria e a realidade, ou entre o seu Ocidente ideal e aquele que existe efetivamente" (CARVALHO, 2010, p. 94). O próprio general gaúcho se antecipava às críticas, afirmando que essa conceituação não representava um objeto com correspondência exata na realidade:

Sua atualização perfeita na Terra talvez nunca seja mesmo possível, mas, nem por isso, deixou ele em tempo algum ou deixa realmente, ainda hoje, de estimular toda essa aventura extraordinária, cheia de êxitos surpreendentes, de falhas irremediáveis, de fracassos tremendos, de deserções e arrependimentos, de dedicações e renúncias que é a longa história em verdade vivida pela sociedade ocidental. (SILVA, 1981a, p. 225)

Quantos aos erros históricos cometidos em nome desse Ocidente, observava o autor, "esses crimes, essas espoliações, essas tiranias, se como tal são reconhecidas e como tal estigmatizadas, afinal, é à luz daquele próprio ideal que conspurcam e, ao renegar, reafirmam" (SILVA, 1981a, p. 225). A essa "corrente de ideal" que impulsionaria a história do Ocidente estariam ligadas inclusive, embora a contragosto, aquelas forças que agora o combatiam ou lhe eram simplesmente apáticas. Segundo o autor conservador, estes eram incapazes de vencê-la, "a não ser na transitoriedade sempre fugaz de certos períodos retrógrados ou na circunscrita delimitação de alguns núcleos reacionários” (SILVA, 1981a, p. 225). Ele ia além de garantia que, se porventura algum dia "o Ocidente perder de todo aquele ideal, aquela fé que o ampara, aquele propósito superior que o guia, terá, então, soçobrado de fato num ocaso derradeiro e fatal” e encontrará também o seu fim, como outras civilizações antes dele (SILVA, 1981a, pp. 226-7). Sob a influência dos filósofos da história citados, o autor em relevo afirmava inclusive que, considerando suas fases sucessivas de evolução, "o Ocidente, na verdade, apresenta analogias, talvez muito mais flagrantes e sugestivas, com as idades 'contemporâneas' de outras civilizações ou culturas” (SILVA, 1981a, p. 222). Assim, sua visão histórica do Ocidente é um "complexo mosaico de caráter fatalista, porém não absoluto, justamente porque o composto de uma dualidade entre o pessimismo de Spengler e a esperança de Toynbee" (BIRKNER, 2002, p. 14). 
Esse Ocidente, nosso século o veria ocidentalizar todo o planeta, "Pelo domínio muitas vezes desumano e cruel ou pela criação de novas civilizações em remotas paragens desertas, mas, sobretudo, pelo poder de fascinação de sua cultura tão bem-sucedida" (SILVA, 1981a, p. 227). Apoiado no "poderio esmagador de uma tecnologia surpreendente", o Ocidente impôs-se às culturas exóticas, "mesmo as de longa tradição de vigorosa originalidade e de um rico passado milenar" que, divididas entre a desconfiança natural e a admiração mimetizadora, viram-se compelidas a "assimilar, o mais rapidamente possível, dessa civilização estranha, tudo o que lhes permitisse reagir, no prazo mais curto, contra a lenta asfixia, a dominação brutal, o deperecimento certo". Usar as armas - técnicas, mas também ideológicas - do agressor para melhor combatê-lo foi a via possível para tais civilizações (SILVA, 1981a, p. 227).

Parece-nos que o raciocínio golberyano oscila entre uma visão mais ancha, abarcando toda a ocidentalidade em seu projeto; e um projeto que se pretende nacionalista, orgulhosamente. Lembremos, para começar, que o estado havia sido criado para garantir segurança ao homem, mas o liberalismo o teria desviado de sua ingente tarefa, tornando permanente a insegurança que em Hobbes era adstrita ao estado de natureza: "Hoje, a insegurança do homem é a mesma, maior ainda, talvez", do que aquela que provocara o surgimento do estado (SILVA, 1981b, p. 362). Assim, hoje, numa era de guerra total e riscos atômicos de completa aniquilação, a insegurança seria ainda mais acentuada; a humanidade estaria disposta até a se escravizar para sentir-se mais segura, optando "unilateral e paradoxalmente", pelo "sacrifício completo da liberdade em nome da segurança individual e coletiva" (SILVA, 1981a, p. 9).

O grande responsável pela falha da tentativa de conseguir segurança pela criação do estado fora o liberalismo ${ }^{10}$, que pregava o estado abúlico, fraco, indefeso e, assim, minimizava o poder estatal. A democracia liberal, já teria ficado demonstrado, estava esgotada. A pressão das massas, entre outros fatores, exigiria mudanças no seu modo de ser. Primeiramente, em suas "veneráveis fórmulas jurídicas", cuja inanidade e insuficiência se patenteariam com a "tumultuosa "invasão vertical dos bárbaros", "sintoma mais relevante da acelerada mobilidade social destes dias que correm". A ultrapassagem "das simples e reconhecidamente vãs liberdades políticas” pelos indivíduos se chocaria com os outros interesses de outros grupos e com as responsabilidades acrescidas do próprio estado. Este fora obrigado,

\footnotetext{
10 Aqui também o autor se contradizia: ao mesmo tempo em que entendia que o liberalismo em todo lugar havia fracassado (inclusive lá onde fora criado originalmente, a Europa) - uma continuidade com o pensamento conservador brasileiro -, por outro lado acabava retomando dos filósofos da história a noção da existência de culturas cooperativas e culturas competitivas, sendo a competição elemento fundamental na evolução histórica.
} 
em prol da eficiência, "a ampliar cada vez mais a esfera e o rigor de seu controle sobre uma sociedade já cansada e desiludida do liberalismo fisiocrático de eras passadas". O decréscimo da solidariedade do cidadão ao organismo nacional em nome da sua dependência a vários grupos com interesses e fins frequentemente divergentes, quando não se demonstram antagônicos; a inexistência de justiça social; a contradição entre a liberdade de imprensa e a manipulação; e, por fim, a própria possibilidade de uma ética do poder seriam questões irresolvidas (SILVA, 1981a, pp. 201)

Assim, para o general, diante de um mundo que lhe exigiria novas características, "Ou a democracia se renova e avigora ou irá sucumbir (...) nos braços ásperos do cesarismo" (SILVA, 1981a, p. 21). Mas, embora a democracia nos moldes liberais tivesse fracassado e precisasse ser repensada, nunca deveria ser de todo desprezada, uma vez que "Somente o regime democrático, com sua nobre escala de valores sociais, permite, de fato, em plenitude uma expansão criadora da personalidade humana e assegura, por via talvez mais longa e caprichosa sob certos aspectos, um progresso efetivo da civilização e do homem.” (SILVA, 1981b, p. 410). Além disso, continuava ele, "a democracia - como fórmula de organização política”, juntamente com a ciência e o cristianismo, é o que caracterizaria o próprio Ocidente (SILVA, 1981a, p. 226). Seria dever moral imperativo, "envidar todos os esforços no sentido de salvar, pela humanização do poder, o futuro da democracia e da humanidade" (SILVA, 1981b, p. 175). Frisava, por fim, que rejeitar o liberalismo não significava rejeitar também a "liberdade que é exigência essencial e impenhorável da condição humana” (SILVA, 1981b, p. 364). Pelo contrário, como a civilização ocidental teria grande apreço pelo homem, não poderia rejeitar a liberdade que é parte integrante da natureza humana: “A liberdade democrática é um valor inestimável para a civilização do Ocidente, e renegá-la, em face do agressor totalitário, seria, no fundo, confessar-se a priori vencido.” (SILVA, 1981a, p. 237)

Ainda no tocante à situação do mundo atual, o autor observava que as próprias elites deixaram de cumprir suas tarefas históricas. Como visto, ele acreditava que, para poder conduzir sua geração ao progresso, com profundidade e realismo, evitando-se as posições demagógicas, "as elites precisam ter desafios pela frente para que sejam capazes de manter a criatividade na condução dos negócios do país. Elite, sem contestação, acaba perdendo inteiramente o poder criador" (SILVA, 1981b, p. 307). Atualmente, porém, as elites, especialmente as brasileiras, estariam demonstrando despreparo para desempenhar suas tarefas, tendo-se transformado de elites criativas em "minorias dirigentes inescrupulosas e ávidas", "tirânicas ou predadoras", "insaciáveis e corruptoras”, que se 
especializariam em "explorar cinicamente a lealdade sincera e muitas vezes desarmada do cidadão comum", manipulando-o em prol de "seus próprios interesses inconfessáveis", que, "sob racionalizações mais ou menos bem urdidas", contrabandeariam para dentro dos objetivos nacionais (SILVA, 1981a, pp. 11; 98; SILVA, 1981b, p. 366). "É, sem dúvida, uma usurpação" (SILVA, 1981b, pp. 326; 439). Assim, em seu tempo, "a grande, a maior, a mais rendosa tática é sempre a da mistificação do povo, apresentando-se-lhes interesses secundários e mesquinhos de minorias insaciáveis e corruptoras sob a roupagem vistosa ou inocente de supostos interesses nacionais, como tais impostergáveis" (SILVA, 1981a, p. 99). Tal tarefa seria atualmente facilitada, pois viveríamos numa "época singular de técnicas aperfeiçoadíssimas no manejo sutil das massas, sobretudo as desarraigadas e quase sempre disponíveis e inconstantes massas citadinas" (SILVA, 1981a, pp. 98-9).

O fenômeno destacado pelo autor, que poderíamos denominar de falsa universalização de interesses, poderia ocorrer porque a elite dirigente seria "compenetrada melhor de seus próprios objetivos, bem equipada para a ação política e sobretudo hábil no manejo sutil dos múltiplos controles sociais" (SILVA, 1981a, pp. 10-11). A manipulação ocorreria "nos estados autoritários - sem rebuços quaisquer, nas democracias - sob disfarces de maior ou menor consistência" (SILVA, 1981b, p. 366). Ele, porém, aporia a tais questões o selo de menos importantes ou acessórias: "Pouco importa que (...) muitas vezes se apresentem como interesses e aspirações da coletividade, alguns que o são, afinal, apenas de uma simples minoria" (SILVA, 1981b, p. 366). Se a elite atua interpretando adequadamente os interesses nacionais e inculcando-os nas massas ou "tratando, maquiavélica ou demagogicamente, de mistificar a massa para que adira a seus objetivos particulares de elite ou coagindo-a tal - isso é, afinal, acessório" (SILVA, 1981b, pp. 10-1).

As elites não encontrariam, sendo assim, nenhum limite para sua ação egoísta - embora as consequências sejam amplamente negativas. Tal displicência com as negatividades da falsa universalização de interesses pode estar ligada à questão da mimesis. Isso quer dizer que o fato de a elite generalizar a defesa de seus interesses para toda a sociedade pode redundar em que eles realmente se tornem interesses gerais, num processo em que

as minorias dirigentes, inescrupulosas e ávidas, seriam levadas a lançar mão de todos os artifícios e todas as formas de mistificação no sentido de apresentar os seus próprios e inconfessáveis apetites egoístas como interesses e aspirações naturais do povo inteiro. Criariam, assim, neste, aos poucos, a viva consciência de que tais interesses e aspirações eram, de fato, algo importante e superior, a ser atendido em permanência (SILVA, 1981b, pp. 394-5). 
A falsa universalização ocorre, sabemos, em várias sociedades capitalistas, mas com maior virulência e selvageria num país como o Brasil, em que as classes dirigentes estão impossibilitadas e, de resto, desinteressadas em representar os interesses da sociedade como um todo. Como não poderia deixar de ser, dado seu enraizamento social, o general se detém aí. Não obstante reconhecesse a importância do tema e a ocorrência do problema, o autor não vai nunca além da simples constatação desse fato.

O esquema hobbesiano pensado para as relações individuais no interior do estado acabou sendo transferido pelo general gaúcho para o plano internacional. Assim, no seu entender, os estados ainda se relacionariam uns com os outros de maneira direta, quase sempre bifrontal, com vassalagens bem definidas, "estruturando-se, atomisticamente, o poder em núcleos esparsos e autônomos" (SILVA, 1981b, p. 368). De acordo com o general, vivia-se, naqueles anos 1950, em um momento de grande dinamismo das relações internacionais e, sobretudo, de alta periculosidade para a existência dos países. No campo internacional, a questão do poder tornara-se fundamental, pois cada estado seria uma unidade de poder que se defronta com outras unidades de poder presentes no mundo, uma nação é um "simples átomo mais ou menos carregado de poder que é a energia fundamental a animar todo o campo das relações internacionais" (SILVA, 1981a, P. 149). Poder que extravasaria muito o âmbito restrito das forças armadas para os campos econômico, psicossocial e o político.

Viveríamos num mundo em que "Os progressos surpreendentes da técnica e da industrialização acelerada rompem (...) a escala de todas as compartimentações espaciais" anteriores (SILVA, 1981a, p. 22). Nenhum recanto do globo estaria imune. As revoluções industriais teriam alterado "profundamente todos os padrões dimensionais, a escala toda do espaço e do tempo" (SILVA, 1981a, p. 73). O mundo atual seria, "hoje muito mais denso e, pois, muitíssimo mais agitado por tensões e atritos de todas as dimensões e da mais variada natureza" (SILVA, 1981b, p. 378), "cheio de contradições e de incoerências, mas, na verdade, um mundo só” (SILVA, 1981a, p. 186). "Há muito que as civilizações ou culturas deixaram de viver mais ou menos confinadas em universos distintos, com suas amplas fronteiras" (SILVA, 1981a, p. 185).

No campo das relações internacionais, o autor ressaltava como fundamental a questão da integração, estreitamento de contato da qual decorreriam necessariamente conflitos, no seu entender. Silva asseverava que seria justamente no âmbito internacional que mais se destacaria a "revolução axiológica" - "a subversão cósmica de valores e de conceitos" que assolaria todos os povos da Terra e que poderia resultar no seu "total 
aniquilamento, se não souber a humanidade resolver a tempo as contradições profundas que aquela subversão por si mesma denuncia" (SILVA, 1981a, pp. 20-1). Para o general, "O símbolo de nossa era é bem o símbolo da integração, processo solucionador por excelência de todos os antagonismos e que melhor convém ao espírito faustiano do homem moderno, inimigo de todas as limitações" (SILVA, 1981b, p. 21). Assim, vão sendo derrubados todos os tipos de "barreiras isolacionistas" "que compartimentavam e compartimentam ainda a grande fraternidade humana - as distâncias físicas e as distâncias sociais, os obstáculos naturais e os estereótipos disjuntivos, os preconceitos de raça, de cultura, de nacionalidade e riqueza, o artificialismo reacionário das cortinas de bambu e de aço" (SILVA, 1981b, pp. 16-7). A força que as demole viria dos novos meios de comunicação de massas, do poder do mimetismo e da mobilidade social horizontal e vertical, num dinamismo que transforma as "relações entre indivíduos, entre estamentos e classes, entre estados nacionais, obriga a um contacto nivelador cada vez mais estreito" (SILVA, 1981b, pp. 16-7).

O autor via este "processo interativo e acelerado" ampliado à Terra toda, prenunciando uma espécie de aldeia global, "a alvorada de uma Weltanschauung realmente universal, uma perspectiva ecumênica, uma comum axiologia, uma consciência verdadeiramente mundial, servindo de amplo quadro em que se situem, e se integrem, e se espelhem as variedades individuais, regionais ou grupais, como todo o colorido próprio de suas visões muito mais particularistas" (SILVA, 1981b, p. 17). De fato, o general considerava o "processo acelerado de massificação no seio da sociedade contemporânea" talvez o fenômeno mais alarmante da atualidade (SILVA, 1981b, p. 15).

Para o general, agora não se tratava mais só de o estado garantir a segurança (ou a ordem), mas também um nível mínimo de bem-estar (desenvolvimento, progresso) para sua população, abaixo do qual a própria segurança se veria ameaçada:

À medida que se sacrifique o bem-estar, em proveito da segurança, canalizando recursos daquele para esta, o primeiro decresce, enquanto a segurança aumenta mais que proporcionalmente, a princípio; a partir de certo ponto, porém, sofre a curva acentuada inflexão, e os acréscimos, agora cada vez menores, acabarão por se anular de todo, quando se haja alcançado o que, teoricamente, corresponde ao máximo de segurança compatível com a limitação imposta pelos recursos disponíveis. Reduza-se, ainda mais, o bem-estar, e a própria segurança se verá, agora, decrescida (SILVA, 1981b, p. 370).

Segundo tal raciocínio, os países pobres estariam à mercê de ameaças à integração nos campos político, psicossocial e econômico, condição fundamental da própria sobrevivência do estado: "uma ameaça 
de desintegração social, de cisão, de cisma no seio da comunidade nacional é sempre um desafio dos mais sérios à própria sobrevivência do estadonação" (SILVA, 1981a, p. 169). Para o autor esguiano, portanto, a "teoria ultrassimplificadora" da luta de classes marxista, "a despeito de sua rigidez e unilateralidade grosseira", teria um fundamento real, mas muito amplificada, ao nível de uma "guerra civil" (stasis) (SILVA, 1981a, p. 98; 1981b, p. 173). Da forma como estava constituído o mundo, "A estrutura íntima do estado - estrutura política, econômica e social - vê-se forçada, portanto, a amoldar-se às exigências e às limitações impostas pelo sistema vigente de relações internacionais" (SILVA, 1981b, p. 480). E, se às exigências dessa realidade ninguém pode escapar, isso é especialmente válido para os estados pobres:

\begin{abstract}
Se a tais imposições externas podem furtar-se, embora nunca de todo, as três, ou melhor, as duas superpotências ou verdadeiros estados imperiais que hoje dominam o panorama internacional, uma vez que a vastidão e diversidade de seus recursos lhes permite quase alcançar a autossuficiência econômica na paz como na guerra - única fórmula segura da liberdade e independência absolutas -, os demais estados e, sobretudo, aqueles que ainda não souberam, ou não puderam, valorizar o potencial latente de seu território e de sua população (...) devem antes reconhecer aquele fato como base de todos os seus planejamentos do que construir na areia movediça de um isolacionismo enganador e perigoso - pois que irreal - os planos, de antemão fadados ao insucesso, de um futuro de prosperidade e grandeza. (SILVA, 1981b, p. 480)
\end{abstract}

Por outro lado, a pobreza não seria agora apenas um problema interno, mas também internacional. Segundo Silva, já pertenceria à história a era do expansionismo europeu, "otimista e descuidado, que canalizava para plagas longínquas as ambições e as agressividades das grandes potências imperialistas" (SILVA, 1981b, pp. 29-30), bem como teriam sido ultrapassados os "tempos remansosos" "em que as nações fracas e pobres de recursos podiam viver e prosperar até certo ponto livremente", de forma marginal em relação aos "antagonismos ferrenhos, mas espacialmente circunscritos, dos poderosos da época, sem que a fraqueza e o relativo pauperismo se convertessem em danosas e agourentas vulnerabilidades ante agressores sempre dispostos a explorálas em seu benefício próprio" (SILVA, 1981b, pp. 29-30). Daí que o general gaúcho advertia as nações do centro capitalista: "nesta quadra de agourentos e apocalípticos sismos sociais" (SILVA, 1981a, p. 185), o "planeta não pode mais acolher, ao lado de nações abastadas, poderosas e prepotentes, a miséria chocante e, sob todos os aspectos, altamente perigosa, da humanidade que se agita e sofre e procria com altíssima taxa de natalidade, nos rincões menos favorecidos da terra” (SILVA, 1981a, pp. 
206-7). Os povos marginais a uma civilização antes pujante e agora ameaçada de declínio, já não tão fascinados pelas técnicas e práticas desta cultura (os quais buscaram assimilar), estavam se rebelando, seja em nome de um nacionalismo xenófobo, seja no de uma revivescência religiosa ou, ainda, do comunismo internacionalista (SILVA, 1981b, p. 173). A pobreza ou o "subdesenvolvimento" seria uma ameaça porque estaríamos numa era “cujo dinamismo potente, incoercível, fatal, ameaça transbordar por todo o planeta, submergindo, numa pseudomorfose aviltante e sufocadora, todos os núcleos de civilização e cultura ainda não amadurecidos e suficientemente resistentes" (SILVA, 1981a, p. 170). Por isso Toynbee concluíra que o Ocidente agora se via cercado pelo mundo que outrora cercou, sob pressão de todos os lados num mundo global e sem margens. Donde, a aura pessimista, desencantada, insegura de sua época, nos mais diversos campos.

Em suma, as contradições seriam fortes na sociedade atual, as tensões estariam acumuladas e logo se poderia assistir à eclosão dialética de um novo ciclo. Este bem poderia ser marcado pelo fim da civilização ocidental. As exigências do cenário internacional, inescapáveis, imporiam a cada estado uma série de procedimentos garantes de sua existência e integridade. Não haveria nenhum organismo internacional que pudesse controlar a unidade de poder que é o estado - que só estacaria diante de outro, mais poderoso. A Liga das Nações não teria passado de um "triste aborto de um grande idealismo utópico", e a ONU teria apenas criado "um palco incruento onde se digladiam tenazmente nações inimigas e irreconciliáveis" (SILVA, 1981a, pp. 20-1). Estava descartada, pois, por absolutamente impossível, a crença de que a justiça poderia ser conseguida pelos fóruns internacionais de conciliação de estados egoístas. Dominado o cenário internacional pela guerra fria, cada um dos estados esbarrava com as exigências objetivas da realidade internacional - mesmo que fosse contra seus próprios valores. Campearia no mundo a lei do mais forte: "Os países fortes tornam-se cada vez mais fortes e os fracos, dia a dia, mais fracos; as pequenas nações se veem, da noite para o dia, reduzidas à condição de estados pigmeus e já se lhes profetiza abertamente um fim obscuro, sob a capa de iniludíveis integrações regionais", profetizando-se um mundo com "constelações feudais de estados-barões rodeados de satélites e vassalos” (SILVA, 1981a, p. 22).

Visto que a guerra como instrumento da política seria uma imposição da realidade, o autor criticava duramente os que ainda conseguiam defender os velhos sonhos de paz universal. Os trechos acima demonstram um profundo cinismo, que se passa por realismo, claramente a serviço da legitimação do status quo no campo internacional. No salvese-quem-puder em que se teria transformado nossa "era perturbada", ele 
não podia conceber como ainda se acreditasse na justiça internacional ou na

intangível liberdade das nações (...) e nesse princípio, tão lógico, tão moral, mas não menos irreal, da autodeterminação e absoluta soberania dos povos, o qual, nem por não se poder nele confiar, de forma alguma importa que se deixe de usá-lo e defendê-lo a todo custo como argumento único, que é, dos fracos contra os fortes (SILVA, 1981a, pp. 20-1).

Ele apelava a para um tema fortemente irracionalista em sua apologia da guerra como geradora de novidades"11: "Mais uma vez a guerra, por si mesma ou pela perspectiva de sua ocorrência, determinará a apuração decisiva de uma técnica nova, para progresso da humanidade" (o planejamento democrático) (SILVA, 1981b, p. 25). Concordava que a guerra deva ser malsinada, mas acreditava que não se pode esquecer que ela também é a mãe de todas as coisas, ou pelo menos de algumas coisas importantes, e lembrava a "influência quase decisiva da guerra na revolução surpreendente da técnica e, pois, da civilização e das culturas" e, por outro, como "a guerra veio a ser, em verdade, um fator capital na implantação dos princípios e das práticas democráticas” (SILVA, 1981b, p. 394, grifos nossos). A guerra teria se extravasado para outros campos pela guerra total e no tempo pela guerra fria - esta, a "única paz que realmente nos é dado conhecer" (SILVA, 1981a, pp. 236-7).

Por isso, o autor não se cansava de repetir: "dúvidas não poderá haver de que o Ocidente se acha ameaçado e ameaçado seriamente", e em todos os seus recantos (SILVA, 1981a, p. 230). Tratar-se-ia de um conflito de "profundas raízes ideológicas" em que "o materialismo comunista do Oriente" e "a civilização cristã do Ocidente" jogariam "pelo domínio ou pela libertação do mundo" (SILVA, 1981a, pp. 186-7). Neste "mundo que dia a dia se encolhe", "Não há mais lugar para 'esplêndidos isolamentos' nem o isolamento seria possível, nem, se o fosse, poderia aspirar a ser suportável, quanto mais a ser esplêndido" (SILVA, 1981b, pp. 29-30; 1981a, p. 144). Na guerra fria, as forças armadas desempenhavam apenas um papel potencial ou demonstrativo, já que o esforço maior vinha sempre de outros campos: o econômico, o psicossocial, ou "o propriamente político, através da atuação de partidos simpatizantes, de alianças partidárias de toda ordem, da quinta-coluna sempre ativa, de toda a atividade preparatória dos golpes de estado ou das próprias insurreições” (SILVA, 1981a, pp. 236-7). Outra característica é que "se o próprio da

\footnotetext{
${ }^{11}$ No decorrer deste trabalho, deparamo-nos com a questão de qualificar - ou não - o pensamento de Golbery do Couto e Silva como irracionalista. Apesar de entendermos como importante tal passo, esclarecemos que esta não é uma das pretensões deste texto, pois só seria realizável em outra pesquisa: o objeto aqui recortado não é o mais adequado para se aprofundar nesse tema, como seria, por exemplo, sua propositura de planejamento democrático e a epistemologia por trás dela.
} 
guerra fria é apresentá-la sempre, de boa ou má-fé, como imputável unicamente ao antagonista, a guerra propriamente dita cada vez mais escapa ao formalismo das prévias declarações de hostilidades" (SILVA, 1981a, p. 207).

Esse antagonismo seria atualmente o dominante, porque teria autonomia e força decisiva suficientes para determinar as relações entre as nações ou coligações de nações, e seria forçoso reconhecer sua centralidade. Pela noção de antagonismo dominante, ele buscava expressar o choque "entre civilizações e culturas distintas quando das fases decisivas dos encontros entre elas”. Por meio destes - e a inspiração, ainda aqui, é Toynbee - "as civilizações alcançam a integração de seu ecúmeno ou desaparecem e morrem" (SILVA, 1981b, pp. 210-1). Diante de um conflito de tal magnitude, "não poderão sequer escapar, nos momentos decisivos, os propósitos mais reiterados e honestos de um neutralismo, afinal de contas, impotente e obrigatoriamente oscilante" (SILVA, 1981a, pp. 186-7). "Como se o que estivesse realmente em jogo fossem simples interesses particulares dos opulentos ianques e não a questão vital da própria sobrevivência de todo o mundo do Ocidente!...” (SILVA, 1981a, p. 241). Pelo conceito de "antagonismo dominante", o escritor conservador pretendia encobrir todos os outros antagonismos: países economicamente dependentes e imperialistas, classes dominantes e classe dominada.

Importante observar que, de acordo com os próprios ensinamentos do autor em tela, "o sentimento de solidariedade entre nações de uma dada região qualquer será sempre tanto mais forte e resistente quanto mais sérias e prementes forem as ameaças externas" e a solidariedade regional dependerá do "grau de sensibilidade das próprias nações interessadas, em relação a essas agressões" (SILVA, 1981a, pp. 175-6). Deixar de tomar uma posição, num conflito em que a própria sobrevivência do mundo estaria em jogo, seria um erro grosseiro e potencialmente letal, mas antes de tudo falso. Nesse sentido, a transformação da disputa entre duas superpotências num conflito de civilizações era bastante conveniente e útil: a neutralidade não seria só impossível, mas também imoral, quando estaria em causa a sobrevivência da própria civilização ocidental. O Ocidente estaria, assim, ameaçado como que pela realização de uma antiga profecia, de um destino trágico e inelutável, mesmo contra todos os esforços envidados em contrário. É novamente História impiedosa, manipulando os cordéis dos homens - e das massas continentais e das civilizações abstratamente consideradas - independentemente de sua vontade e de suas ações.

Silva ressaltava o acerto da estratégia de contenção/isolamento do comunismo, já que uma estratégia de repulsão seria "impraticável e suicida”, incorreria num “crime injustificável e até contraproducente" se incentivasse a rebelião inútil de populações indefesas sob uma tirania 
totalitarista disposta a tudo. Também não seria possível, além do "mero esforço de imaginação de alguns publicistas exaltados ou teóricos com os pés nas nuvens", a guerra preventiva, de vez que o Ocidente não poderia desencadeá-la (SILVA, 1981a, p. 241). Nesse conflito fatal, a vantagem imediata de ação estaria com o bloco comuno-soviético, pois o Ocidente tinha menor potencial humano disponível para uma guerra tradicional e teria dificuldade de tomar a iniciativa de uma ofensiva estratégica atômica, diante dos "indiscutíveis efeitos desmoralizantes de uma tal decisão numa sociedade "educada nos princípios humanitários e superiores de nossa ética cristã” (SILVA, 1981a, p. 230). Por essa lógica, dadas as desvantagens de viver em um mundo apontado como livre e democrático, "o desencadeamento brutal de uma guerra atômica irrestrita só possa surgir por decisão fria e calculista dos senhores absolutos do Kremlin" (SILVA, 1981a, p. 230). É impressionante o quanto a interpretação golberyana paira sobre a história e desconhece os processos reais - pela sua lógica, Hiroshima e Nagasaki jamais teriam ocorrido, e, no entanto, ocorreram antes de ele escrever os trechos acima, ainda que num contexto anterior ao da guerra fria, ainda que correlacionado a ela.

Conforme observava o autor, a guerra fria era necessariamente mundial, envolvia e buscava envolver todo o planeta. A estratégia do bloco comuno-soviético era dúplice: tentava atrair os povos não-ocidentais e "espalhar a cizânia, a desconfiança e o caos" no próprio mundo ocidental, "enfraquecendo-o e dissociando-o com a sua pregação antiamericanista, anticapitalista, anticristã, materialista e demagógica" (SILVA, 1981a, pp. 237-8). O “agressivo neutralismo dos não-alinhados” e o "indisfarçável antiamericanismo" da terceira via de Perón seriam exemplos de sucesso dessa estratégia (SILVA, 1981b, p. 480). Também aqui as maiores desvantagens seriam ocidentais, já que não poderiam mudar bruscamente de atitude sem perder prestígio, romper alianças e desagradar os neutros. Ademais, este Ocidente - agora homogeneizado - é "uma sociedade democrática, aberta à infiltração da propaganda inimiga e que, respeitando a consciência do indivíduo e a dignidade da pessoa humana, não pode reprimir com eficácia a atuação desagregadora da quinta-coluna soviética" (SILVA, 1981a, p. 237). Os comunistas teriam maior liberdade de ação, conseguiriam empenhar melhor seus teleguiados e as "forças de voluntários" nas guerras localizadas - sejam as "guerras por procuração", sejam aquelas em que os grandes intervinham abertamente -, ao passo que "os Estados Unidos não terão outro remédio senão intervir às claras, com suas próprias Forças Armadas”, arriscando sua imagem e seu prestígio internacional (SILVA, 1981a, p. 239). Novamente, um raciocínio completamente desmentido a partir da década de 1960, quando pulularam 
na América Latina golpes militares dirigidos e/ou apoiados pelo país líder da "democracia" e da "liberdade", cujos aliados não seriam "teleguiados".

Para Golbery do Couto e Silva, portanto, a civilização ocidental estava "talvez já ferida de morte, assustada e perplexa ante o espetáculo histérico desta quadra agônica em que vivemos" (SILVA, 1981b, p. 13) em que as massas bárbaras, que desta civilização dominadora, "práticas e técnicas - não o espírito - buscaram e ainda buscam assimilar", estariam se rebelando mais ou menos abertamente (SILVA, 1981b, p. 175). De fato, segundo o general da ESG, já se havia passado por muitas tentativas de implantação do "estado universal", entre as quais citava as guerras napoleônicas e os dois conflitos mundiais. Isso para reafirmar seus temores de que, numa era atômica, ameaçavam sobrevir conflitos ainda mais mortíferos - motivo pelo qual "projeta-se e proclama-se e defende-se, já quase mesmo sem fé, a criação de uma 'comunidade de poder', de um controle institucional supranacional, de qualquer forma estável e não despótica de ordem universal" (SILVA, 1981b, pp. 172-3). Ou seja: a civilização ocidental passava por um "período crítico de perturbações violentas" semelhante aos que "sempre precederam o estabelecimento pela força de um estado universal, criado através de múltiplas guerras, pelo último remanescente ainda vitorioso" (SILVA, 1981b, pp. 172-3). E aqui se somavam Spengler, Toynbee e Ratzel (este com a "era da história continental") para concluir que havia supostos indícios claros de novas instituições de relacionamento no âmbito internacional num futuro mais ou menos próximo: um superleviatã, o organismo político multinacional que o próprio panorama internacional de guerra total exigiria - mas talvez desse lugar ao império universal, que poderia significar a aniquilação da civilização ocidental.

É que, talvez, se esteja realmente a esboçar uma nova ordem para o mundo: senão - praza aos céus evitá-lo! - o império universal, com sua paz ecumênica, mas seu incontrastável e despótico cesarismo interior - a cristalização do poder em unidades de larga base geográfica, verdadeiras panregiões de economia e organização social superiormente equilibradas. (SILVA, 1981a, p. 215)

Por outro lado, a gravidade, multiformidade e onipresença das ameaças a que se expunha obrigaria o Ocidente a enquadrar em uma estratégia coerente e coordenada todos os estados ocidentais. Para tal tarefa, a supremacia dos Estados Unidos era incontestável - embora o autor não se refira a eles com os termos "estado universal” e menos ainda com “império universal”. Em relação à América Latina, este país teria pautado por longo tempo sua conduta internacional pela lógica do destino manifesto e do big stick, até que, no pós-guerra, assumiu a contragosto as responsabilidades e prestígio decorrentes da liderança da civilização 
ocidental e passaram a valer-se "de que outros processos e outras técnicas de persuasão", tidas como mais produtivas para alicerçar a defesa continental (SILVA, 1981a, pp. 28; 175). Esse histórico de ingerências negativas, reprováveis e egoístas desse país teria gerado ressentimentos na América Latina, os quais já teriam sido superados em prol da disseminação de um "nacionalismo sadio", que agora inclusive clamaria pela ajuda estadunidense para solucionar problemas internos aos diversos países.

Seria necessária grande habilidade diplomática para manejar o prestígio e a supremacia sem gerar idiossincrasias, mas experiência estadunidense "nesse particular, deixaria muito a desejar". Segundo afirmava o autor, era natural que, diante da estratégia de conter o comunismo em suas atuais fronteiras, os Estados Unidos concentrassem esforços na estruturação, no fortalecimento de material de guerra, na cooperação econômica e na manutenção de poderosas forças militares nas proximidades, bem como no elevado nível do poder de intimidação atômica. Mas, com isso, o restante do mundo (a África quase toda e as Américas, tanto Central como do Sul), "ficaria relegado a um segundo plano bem nítido nas preocupações e assistência dos Estados Unidos, quase inteiramente guiadas, aqui, ainda por interesses imediatistas e inconfessáveis dos altos círculos financeiros daquele país" (SILVA, 1981a, p. 239). Os cuidados "pela manutenção de uma solidariedade continental idealista e nobre" padeceriam "os mais diretos reflexos" do maior comprometimento dos Estados Unidos no além-mar, levando-os "a descurar as tensões que agitam, subterraneamente, o edifício imponente, mas pouco sólido" do pan-americanismo ainda imberbe (SILVA, 1981a, p. 175). Assim, aquele país não compreendia que, para a construturação de uma aliança ocidental, havia que atender, em primeiro lugar, aos interesses dos aliados, e só secundariamente os dos neutros, forma de alcançar "um grau mínimo de concordância geral, indispensável à existência verdadeira do que merecesse o nome de uma estratégia coletiva ou coordenada de todo o mundo ocidental" (SILVA, 1981a, pp. 239-40).

Era o protesto do nacionalista ressentido, incomodado com o fato de o líder ocidental não reconhecer a importância do Brasil para a defesa ocidental e, por conseguinte, não o tratar com a devida deferência. A questão que fica em aberto, como observou Carvalho (2010, p. 94), é: como se pode assegurar que as ações dos Estados Unidos visariam ao bem de toda a civilização, devendo ser apoiadas, e quando estariam voltadas aos interesses específicos dos Estados Unidos ou, ainda pior, de seus altos círculos financeiros? O general chegou a resvalar essa questão, sem nunca resolvê-la e nem mesmo formulá-la diretamente. Ele acabava, pelo contrário, reiterando a necessidade da atuação direta estadunidense em 
defesa do Ocidente, "a despeito da desconfiança que sempre suscitarão quaisquer intervenções suas em virtude de um longo passado, não de todo olvidado, de detestáveis práticas colonialistas" (SILVA, 1981a, p. 229).

De outra parte, uma das implicações daquela quadra mundial de interdependência entre os estados seria a rediscussão do conceito de independência e de soberania. Afinal,

Nada do que um estado resolva ou deixe de fazer no cenário internacional ou mesmo no próprio âmbito interno - já que estas últimas atividades necessariamente terão sempre repercussões exteriores, por enfraquecerem ou fortalecerem, em maior ou menor grau, o seu próprio potencial nacional - poderá ser realmente indiferente, nos dias de hoje, a outro estado qualquer. E note-se que uma nação determinada (...) se encontra a defrontar-se com mais de 80 outros estados, (...) os quais se apresentam, além do mais, constituindo largas malhas de interesses mais ou menos solidários através de organizações das mais diversas. (SILVA, 1981a, p. 149)

Assim, apesar das já citadas indicações de que estaria por vir uma nova ordem internacional, dominada por entidades multinacionais, a soberania ainda seria um dos atributos mais necessários a esse "organismo político" que é o estado, e sem a qual não poderia sobreviver. Como observou Carvalho, há

certa tensão, que não aparece explicitada na obra de Golbery mas que é impossível não notar em uma análise mais detalhada, entre a visão de um mundo totalmente "anárquico" e estadocêntrico e a visão do mesmo como dividido em civilizações (um conceito que limita a liberdade de ação dos estados, fazendo reduzir a "anarquia" do sistema). Só é possível resolver o problema ao se postular dois níveis de análise estatal e civilizacional - com influência entre si mas essencialmente separados. Alguns filósofos da história deram esse passo, mas Golbery não se preocupou com o problema, o que é uma nova limitação de seu pensamento (CARVALHO, 2010, p. 98).

\section{Entre o nacionalismo e a opção ocidental, o Brasil}

Olhando o mapa-múndi desde uma perspectiva geopolítica brasileira, Silva distinguia um hemiciclo interior, num raio médio de $10.000 \mathrm{~km}$ da América do Sul, abrangendo a América do Norte, a África ocidental e a Antártida. Este era circundado por um hemiciclo exterior, balizado, grosso modo, por um arco de $15.000 \mathrm{~km}$ de raio e que englobava a Eurásia, a África Oriental, a Austrália e parte da Antártida. Para além desse hemiciclo exterior, havia ainda a China, Japão, Indonésia, Malásia e Filipinas. Do hemiciclo interior, conforme seu raciocínio, não haveria a temer qualquer ameaça à nossa segurança, em primeiro lugar pela 
ausência potencial de agressão, mas também pela presença possante dos Estados Unidos, além da “zona psicológica de amortecimento" formada pela "comum profissão de fé democrática e o ideal pan-americanista" (SILVA, 1981a, p. 80). Historicamente, o hemiciclo exterior é que teria representado diversas vezes perigo para a América do Sul, situação que se repetiria em sua época (SILVA, 1981a, pp. 135-6).

Por outro lado, segundo acreditava o general, o hemiciclo interior (América do Sul, África e Antártida, basicamente) constituiria de fato "a retaguarda vital de todo o mundo do Ocidente" e do Brasil, cuja penetração importante por um inimigo "comprometerá certamente todo o sistema defensivo do mundo ocidental", especialmente tornando extremamente vulneráveis as comunicações marítimas e aéreas (SILVA, 1981a, p. 191). Assim sendo, o hemiciclo interior "avulta, no dispositivo geral, como fronteira decisiva da segurança sul-americana", a qual estaria garantida enquanto aquelas massas estivessem livres de agressores (SILVA, 1981a, pp. 82; 129-30; 184). Manter a América do Sul, a Antártida e em especial a África, bem defronte ao território nordestino, em “mãos amigas” seria, segundo esse raciocínio, não uma opção ideologicamente fundamentada, mas sim um "imperativo geopolítico, traçado no mapa do mundo pela disposição eterna das massas terrestres que nos circundam" (SILVA, 1981a, p. 184) - portanto, algo neutro, imutável e inescapável.

O Brasil, gestado "sob o signo da própria Cristandade", resultante final da transposição da cultura ocidental europeia "para terras quase desertas e virgens onde não havia cultura autóctone que lhe resistisse ou pudesse deturpar-lhe a essência”, embebido desde sempre nas ideias e nas crenças ocidentais, "não poderia renegar jamais esse Ocidente em que se criou desde o berço e cujos ideais democráticos e cristãos profundamente incorporou à sua própria cultura” (SILVA, 1981a, pp. 226-7). Pertence o país ao Ocidente, tal como este viveria e persistiria no Brasil, no seu corpo e alma, na sua técnica e na ciência, na fé, na linguagem, na paisagem "Nós somos, também, o Ocidente"12 (SILVA, 1981a, p. 227).

Nas alocuções golberyanas há constantes "referências aos valores fundamentais sobre os quais se assentaria a sociedade brasileira e os povos das Américas em geral", que estabeleceriam "as bases morais para as alianças políticas continentais e seus sistemas coletivos de defesa”. Esse conjunto cultural "consistiria de um legado das civilizações antigas, como a judaica, grega e a romana, que, aliado aos elementos da modernidade, formalizariam a base para a atuação do estado brasileiro" e do Ocidente (NASCIMENTO, 2013, pp. 151-2).

12 Em Spengler havia uma dubiedade quanto à territorialidade do Ocidente: em alguns momentos abarcaria exclusivamente o território da Europa ocidental, em outros incluiria a América (SILVA, 2008, p. 66). 
No tocante à sua situação interna, o Brasil não escaparia às determinações da realidade em que estava inserido, antes ao contrário: Silva avaliava que, num mundo "em vertiginosa ascensão para novos e revolucionários padrões", o fato de o Brasil ser "uma nação em crítico e ainda rudimentar estágio de seu desenvolvimento econômico e social” o caracterizaria como "um país potencialmente agredido". O subdesenvolvimento econômico era, pois, visto por ele como uma falha potencialmente muito perigosa na política de segurança nacional, e pois sua solução deveria ser prioritária, pela rápida industrialização, com ampliação da infraestrutura econômica, a redução dos pontos de estrangulamento, a diminuição disparidades entre setores (SILVA, 1981b, p. 25). "É que ao Brasil, na hora presente, só há uma escolha: engrandecerse ou perecer!” (SILVA, 1981a, p. 62) Como o Brasil era um país de poupança muito baixa, tentar resolver seus problemas com recursos próprios levaria muito tempo, implicaria muitos sacrifícios e não teria garantia de êxito.

A alternativa, para ele, era lógica: o recurso à poupança externa. Daí que "o Brasil essencialmente depende - e quanto! - do restante do Ocidente e, em particular dos EUA, para o seu comércio, o seu desenvolvimento econômico, o seu progresso técnico e cultural, até para a sua própria segurança” (SILVA, 1981b, p. 248). O objetivo era tornar o Brasil uma potência de nível mundial, pois apenas as potências desse nível estariam, e apenas temporariamente, livres de grandes antagonismos. Evidencia-se, aí, o dilema que perpassava a ideologia golberyana: ser nacionalista e estar votada à sobrevivência da civilização ocidental.
A operação mental que o general Golbery pretende fazer - construir uma geopolítica brasileira para auxiliar os Estados Unidos e o Ocidente a defender-se contra o "imperialismo comunista de origem exótica" - é de difícil realização, porque nega, de início, o fundamento mesmo do raciocínio geopolítico, que é a política de poder e a afirmação do poder nacional desvinculado do contexto mais geral da civilização em que se insere (...). Geopolítica e o ecumenismo se excluem logicamente (FERREIRA, 1984, p. 596)

A contradição permanente entre o nacionalismo geopolítico e a opção pelo Ocidente era resolvida pelo autor sob análise proclamando um nacionalismo "que é toda a nossa nobreza" - mas não um nacionalismo simplesmente, e sim um nacionalismo "amadurecido, realista e crítico", que não se chocaria com a opção pela civilização ocidental. Ele ainda ajuntava que o estado soberano admitiria, "ele próprio, autolimitações maiores ou menores de seu poder de soberania, em benefício da paz ou da cooperação internacionais, quando não mesmo em face de certas graves ameaças de sua total destruição” (SILVA, 1981a, p. 168). Mesmo assim, completava, se a generosidade materna da natureza cedeu ao litoral 
brasileiro e ao nosso promontório nordestino posição tão favorável para a defesa do Ocidente, esse trunfo era brasileiro e apenas ao Brasil caberia empregá-lo, "por mais que estejamos, sem tergiversações, dispostos a utilizá-lo em benefício de nossos irmãos do norte” (SILVA, 1981a, p. 168).

Como "o preço do poder é a responsabilidade", o Brasil poderia valer-se dos seus trunfos geopolíticos para a defesa da civilização ocidental - quais sejam, a importância estratégica do Nordeste brasileiro, das matérias-primas nacionais e da embocadura amazônica, ademais de sua "economia não competitiva" e da "larga e comprovada tradição de amizade"; de outra parte, não caberia deixar de aceitar os ônus decorrentes, pois "de forma alguma poderíamos abrir mão de deveres que são exclusivamente nossos, como o da integridade do território nacional e não menos o da segurança do Atlântico Sul ao qual estão vinculadas a nossa prosperidade e, sem dúvida, a nossa sobrevivência” (SILVA, 1981a, p. 52). Um Brasil que assumisse conscientemente seu papel na defesa da civilização ocidental conseguiria "negociar uma aliança bilateral mais expressiva" para seu próprio desenvolvimento e que "traduza o reconhecimento da real estatura do Brasil nesta parte do Oceano Atlântico" (SILVA, 1981a, p. 51). Concluía, portanto, que "o direito de utilização de nosso território", não se deveria “ceder por um prato de lentilhas": a soberania poderia ser objeto de escambo, desde que fosse uma barganha leal - o estatuto do país como aliado preferencial. "Também nós podemos invocar um 'destino manifesto', tanto mais quanto ele não colide no Caribe com os de nossos irmãos maiores do Norte...” (SILVA, 1981a, p. $52)$.

A solução golberyana para a contradição entre a defesa do Ocidente e o nacionalismo era patente, mesmo com as suas tentativas de solucionálas racionalmente. Desembocavam na tentativa de construir o poder nacional contando com a contribuição daqueles países que já são dominantes. Contudo, qual a força dos argumentos brasileiros, se seu apoio aos Estados Unidos, contra a União Soviética, já estaria garantido de antemão, pela sua pertinência ao Ocidente e pelo repúdio ao comunismo materialista e alienígena? Carvalho aponta a "inconsistência" entre um pensamento geopolítico no qual só valem a estratégia e a geopolítica que estiverem embasadas em interesse "estritamente nacional" e, de outra parte, a defesa de um alinhamento automático (2010, p. 113). Aqui, mais que um limite teórico, patenteia-se claramente a ilusão de controle político-estratégico do capital e de seus interesses, ilusão que constituía um limite ideológico do general gaúcho. De forma que o caminho para uma grandiosidade futura, mesmo que com percalços, era, portanto, primeiramente uma opção do próprio Brasil, uma visão voluntarista e muito ingênua. 
O autor também chamava à responsabilidade os países do centro do capitalismo para a importância da tarefa de elevar o nível de vida das populações subdesenvolvidas, em particular do Brasil. Afinal, advertia, "nesta quadra de agourentos e apocalípticos sismos sociais" (SILVA, 1981a, p. 185), não é mais cabível existirem simultaneamente "nações abastadas, poderosas e prepotentes [e a] a miséria chocante e, sob todos os aspectos, altamente perigosa" que vicejava "nos rincões menos favorecidos da terra" (SILVA, 1981a, p. 206). O mundo capitalista, "do qual representamos, nós todos da América Latina, simples elos mais débeis”, precisaria tomar consciência "de que não haverá como combater, com segurança de êxito, as promessas do milênio comunista" senão "oferecendo, aos povos todos subdesenvolvidos da Terra, uma alternativa diversa entre a estagnação e a miséria generalizada, de um lado e, do outro, a industrialização, o progresso material, o poderio nacional, alcançados embora estes, em regime totalitário, à custa de sacrifícios tremendos" (SILVA, 1981a, p. 2489). Uma "grande inconcussa demonstração da vitalidade e poder de criação do próprio regime democrático", uma "experiência em vasta escala, indiscutível e inspiradora", de "soerguimento de povos subdesenvolvidos a um nível elevado de bem-estar, de riqueza e de progresso", seria urgente e imprescindível (SILVA, 1981a, p. 249). Ela patentearia as imensas possibilidades contidas desse regime, respeitando-se as liberdades públicas, de "romper o ciclo deprimente do subdesenvolvimento econômico".

A urgência e importância da ação implicariam pesar a "proporcionalidade do poder ao vulto das responsabilidades e compromissos assumidos" por cada país. Como a América Latina passava por grave crise econômica e social, a realização de tal experiência nessas paragens seria "mais veemente e mais decisiva". Não muito influenciada pelo bloco comunista (o texto havia sido escrito antes da Revolução Cubana), física e culturalmente próxima dos Estados Unidos, com um território e riquezas imensos e quase inexplorados, dispondo de um potencial demográfico importante e profundamente cristã e democrática, a América Latina "constitui vasto e promissor campo para uma tal experiência, generosa sem dúvida, mas também de alta significação para a defesa dos postulados, dos valores, das crenças da civilização toda do Ocidente" (SILVA, 1981a, p. 248-9).

Desta América Latina por si só emblemática, complementava o general, “o Brasil é, em si mesmo, uma expressão e um espelho": seu estágio incipiente de desenvolvimento lhe possibilitaria compreender "o drama de toda a incontável humanidade subdesenvolvida", podendo, por isso, "servir de intérprete fiel a anseios que bem é capaz de medir" (SILVA, 1981a, pp. 197-8). Além do mais, seu prestígio, suas variadas riquezas 
naturais, seu potencial humano e sua "inigualável posição geopolítica" teria importância toda especial para as "imperiosas necessidades de defesa do Ocidente" (SILVA, 1981a, p. 246). Em resumo, o Brasil disporia de todas as condições para tornar-se um especialíssimo lócus de aplicação de uma espécie de Plano Marshall tupiniquim que redundaria em um aumento do desenvolvimento regional, visto que o país integrava todas as áreas geopolíticas do continente. Ademais, seria uma demonstração mundial "a todos esses povos desesperançados e frustrados [de] uma alternativa mais risonha do que a apresentada pelo comunismo" (SILVA, 1981a, pp. 197-8).

\begin{abstract}
Em contrapartida ao cenário de indeterminismo das fronteiras geradas pela imposição de zonas de influência e das disputas delas derivadas, em plena guerra fria, Golbery apresenta o Brasil como um elemento de destaque, (...) que por sua posição geográfica no contexto americano, possuiria o dote de ser um potencial integrador de regiões que guardam entre si identidades semelhantes e também dessemelhanças essenciais, mas que se unem, a despeito de eventuais conflitos de interesses, em termos políticos, culturais e econômicos, por fundamentarem-se no conceito de Mundo Cristão Ocidental. (NASCIMENTO, 2013, p. 23)
\end{abstract}

O Brasil golberyano se arvorava, pois, em representante dos interesses de toda a América Latina e, mais, de todos os povos subdesenvolvidos da Terra, numa experiência ímpar de desenvolvimento democrático. Estaria, em troca, oferecendo às potências ocidentais os meios de que disporia para a defesa do Ocidente. Para tanto, seria necessário o país deixar clara sua disponibilidade - e sua capacidade - aos norte-americanos e às demais nações latino-americanas, por meio de campanha clara, honesta, sem tergiversações.

Aqui a geopolítica se reconciliava com a filosofia da história para reiterar o destino grandioso do Brasil. De acordo com o esguiano, tanto Toynbee quanto Spengler observaram que, quando uma civilização está moribunda, "se produz comumente a transladação dos centros dominantes de cultura e poder, das paisagens originais para zonas periféricas" nas quais brota e viceja, vigorosa, "sejam as mesmas civilizações antigas num derradeiro lampejo de glória, seja civilizações novas libertadas por fim da 'pseudomorfose' asfixiante" (SILVA, 1981b, pp. 219-20).

É a deixa para o general chamar para o Brasil a possibilidade - e a oportunidade - de resguardar os melhores elementos da civilização ocidental para um futuro renascimento. No seu entender, deflagrando-se o confronto atômico, de caráter brutal e catastrófico, entre as duas superpotências que então disputavam o controle do mundo, o hemisfério norte inteiro estaria afundado "em uma treva espessa de desesperação e miséria” (SILVA, 1981b, pp. 219-20). Nesta situação, o Brasil poderia ser 
finalmente alçado ao papel internacional ao qual estaria destinado, eventualmente liderando outra cultura e outra civilização, nascida dos destroços da ocidental, desde que mantido a salvo do blandicioso canto de sereia comunista:

E se o Brasil subsistir em segurança neste gólfão excêntrico do Atlântico Sul, poderá bem ser destino seu recolher a herança de cultura de uma civilização portentosa que se tenha esvaído na loucura da guerra, cumprindo-lhe então, por sua vez, aquela missão histórica que tem cabido a muitos outros povos no evolver impassível dos séculos, em que todos são (...) "como corredores olímpicos passando de mão em mão o facho luminoso da vida". (SILVA, 1981b, pp. 219-20)

\section{Considerações finais}

Golbery do Couto e Silva qualificava-se o tempo inteiro como dialético e incorporava nominalmente a dialética em seu raciocínio. Mas, como demonstramos em outro lugar (ASSUNÇÃO, 1999), escapava-lhe a percepção adequada da realidade, porque as contradições reais não eram admitidas e as rupturas eram apresentadas como potencialmente destruidoras. Seu arraigado conservadorismo o levava a repelir na prática toda possibilidade de transformação radical, o momento final do choque de contradições; e, com isso, rejeitava as próprias contradições, que só desta maneira encontrariam sua solução final, para de imediato engendrar outra espiral choques de contrários. Quando usava o termo contradição, referia-se, na verdade, a conflitos, que pretendia eliminar antes que explodissem. Daí que trabalhasse com dicotomias em vez de contradições - assim, socialidade/conflito, liberdade/segurança e outras -, mesmo acreditando tratar de dialética.

Em termos de estilo, desejando apresentar-se como erudito, tinha uma escrita rocambolesca e artificialmente empolada, repletas de intercalações e digressões intermináveis. A suposta dialética era mais um recurso dentre os que se valia, embora apareça também como forma de abordagem racional dos objetos.

Quanto ao conteúdo, uma das características marcantes do ideário golberyano é o ecletismo (elemento fundamental do pensamento burguês da era da decadência ideológica, cada vez mais incapacitado de elaborar conhecimento coerente): teorias diferentes e até contraditórias eram mescladas, reelaboradas e apresentadas como explicação racional e coerente. Os elementos interessantes e até pioneiros em seu pensamento estavam enformados por um raciocínio pautado pelo ecletismo e pela adialeticidade, o que implicava também a generalidade abstrativante, que desconsiderava a concreção, e o empirismo - seleção de fatos ou 
elementos de acordo com sua conveniência para o argumento -, preços a pagar pela operação frankesteiniana. O autor abraçava teorias díspares, mal as alinhavava, abandonava-as em prol de outras quando se via diante de aporia, e, por fim, apresentava um produto teórico descosido e de baixo nível de elaboração, caracteres elucidativos de seus limites.

$\mathrm{O}$ autor em pauta percebia o ser humano como um animal social, de cuja natureza faria parte o egoísmo: assim, contato e conflitos lhe seriam inerentes, acentuando-se ambos com o passar dos tempos. Donde, a moral ser necessária para manter coesa a sociedade. A liberdade também faria parte da natureza humana, em abstrato, mas na prática era contraditada sempre pela necessidade de segurança. A história humana era vista por ele como repleta de determinismos que não se pejava de chamar de "destino", sem que ele se desse conta da contradição com a suposta dialética que pretendia incorporar e convivendo inclusive com críticas aos determinismos de outros autores. Ademais, os verdadeiros atores estariam acima dos homens comuns: seriam os grupos dirigentes das classes dominantes e o estado. Que os interesses desses possam conflitar com os interesses nacionais é até citado, mas nunca debatido a fundo.

O Ocidente, para general, apesar de dissensões, conflitos e transformações no tempo e no espaço, teria uma identidade muito própria: um propósito, a ciência como instrumento de ação. um ideal, a democracia como fórmula de organização política; um programa, o cristianismo como supremo padrão ético de convivência - três elementos que não só se contraditam entre si como caracterizam momentos pontuais e espaços delimitados do Ocidente. O autor pretendeu escapar da contradição afirmando seu caráter não realizável, utópico.

A situação do Ocidente em sua época mostrava os riscos do subdesenvolvimento e da pobreza para a manutenção da integridade e progresso das nações, internamente, e para a própria segurança ocidental, no campo das relações internacionais. $O$ autor antecipava, assim, a tensão Norte-Sul, então ofuscada pela guerra fria, mas sua constatação visava a se antecipar a possíveis explosões sociais. Para o autor, pensar a realidade tinha como objetivo não sua transformação radical, mas uma modificação controlada, segura e limitada, para que tudo continuasse como estava.

As elites não estariam aptas a cumprir suas tarefas. A ação prática do autor no pré-64 e na articulação entre o núcleo empresarial e o militar durante o regime bonapartista (cf. GASPARI, 2003) era, segundo entendemos, justamente uma forma de suprir as deficiências teóricas e práticas das elites nacionais. Mesmo despreparadas, porém, não se questiona a realização dos seus interesses mesquinhos: mais uma vez, a coesão social era posta acima da coerência com os interesses nacionais. Isso porque um risco de desintegração social seria dos mais graves e 
melhor seria mudar paulatinamente a própria consciência das elites que se arriscar a um revolucionamento social. Nesse mister, a democracia - que não se poderia eliminar totalmente, dado seu caráter instrumental precisaria se modificar para continuar existindo, como ideal de organização política a alcançar. Mas uma democracia restrita, politicista, calculista, formalista, institucional, para o controle das massas e das mudanças a serem implementadas na sociedade.

Na tematização que o autor em tela fez do Ocidente, restou evidente uma contradição entre um estadocentrismo - o mundo ainda seria um conjunto anárquico de estados-nação - e a visão de civilizações em disputa. A questão da lealdade devida a dois senhores, fonte de neuroses individuais e crises sociais, repunha-se com força irônica: quando houvesse choques, ou mesmo dúvidas, acerca de quais interesses estariam em pauta em determinados processos, que critérios embasariam a tomada de decisão entre o interesse da nação e o interesse civilizacional? Silva não enfrentou devidamente esse problema.

No campo internacional, o raciocínio sobre unidades egoístas com maior integração e mais conflitos se repetia, com a agravante de a escala espaço-temporal ter sido bastante reduzida pela industrialização, pelas técnicas e pelas comunicações: o mundo estava se transformando numa aldeia global. Entretanto, clivada por um conflito terrível, potencialmente mortal, entre duas civilizações completamente distintas: o Oriente, apontado como comunista, totalitário, materialista, ateu e exótico; e o Ocidente, tido como cultura própria, tradicional, cristão, democrático - e capitalista, o que significativamente não é dito nunca em voz alta. Que o conflito entre duas superpotências fosse transformado em conflito entre sistemas ("comunismo" x capitalismo) já era reducionista, mas apresentálo como choque de civilizações, com a obrigatória e automática adesão a uma delas, era radicalmente maniqueísta. Ainda mais se a própria civilização ocidental, "que é a nossa", também estava prenhe de contradições que nem mesmo o fervoroso fanatismo ocidental de Silva poderia obnubilar. O próprio autor, porém, "dava o serviço": quanto mais sérias e prementes as ameaças, maior o sentimento de solidariedade; era necessário, portanto, potencializar o medo cósmico que estaria na raiz da sociedade pela ameaça de eliminação pela guerra total atômica.

A sobrevivência da civilização ocidental estaria ameaçada. Sua salvação - ou mesmo o nascimento de outra civilização, cria desta - só seria possível sob a liderança dos Estados Unidos, que, no entanto, não teriam ainda tomado tento das prioridades. Por isso, o general gaúcho pretendia lhes dar conselhos, chamando a atenção para a negligenciada América, e nesta para a centralidade do Brasil. Aqui estariam dadas as condições para salvar o Ocidente por uma experiência de desenvolvimento 
socioeconômico dirigido e financiado pelo país mais rico, de forma controlada pelo alto, sem transformações radicais, a se implantar num país importante, a qual teria a potencialidade de elevar o nível de todo o continente. Seria uma demonstração incontestável ao mundo das possibilidades deste regime "democrático" - a palavra capitalista é vetada.

Desenvolvam o Brasil, salvem o mundo!, era o misto de grito de advertência e palavra de ordem em que se uniam nacionalismo e defesa do Ocidente. Um grito tanto mais alto e lacrimoso quanto mais inaudível pela superpotência líder. Assim, a ideia de controle político das inversões de capital, ainda mais do capital estrangeiro, era o delta onde desaguavam suas ideias políticas. Uma ilusão socialmente necessária de chegar ao desenvolvimento e à autonomia econômicos pela generosa cooperação da potência dominante (e pela intervenção estatal) que era muito mais ampla que um limite pessoal, tendo sido a ambição de vários ideólogos do regime bonapartista. Ademais, não dizia respeito simplesmente a uma deficiência teórico-metodológica do general, nem a uma cínica estratégia diversionista, mas estava posta na própria realidade.

Aqui, somos remetidos à determinação social do pensamento e, assim, obrigados a fazer um breve desvio, antes de concluir, passando pelo principal dos influenciadores do pensamento de Silva no tocante ao tema recortado. Não temos a intenção de fazer uma abordagem comparativa dos dois autores, senão de apontar razões para Silva não o ter copiado ipis litteris e ter apelado ao ecletismo.

A Alemanha de Spengler, por um conjunto de caracteres próprios da sua história - apelidados por Marx de miséria alemã - enveredou pelo caminho do capitalismo de forma tardia em relação a Inglaterra, Estados Unidos e França. $\mathrm{O}$ atraso histórico gerou uma série de consequências, como a queima de etapas e a coalizão de interesses entre as classes remanescentes do feudalismo e a burguesia em ascensão. Precavida pelos eventos revolucionários ocorridos alhures, esta optou pelo cômodo compromisso de classe com aquelas, o que lhe possibilitou escapar dos riscos de uma revolução democrático-burguesa - de que poderia perder o controle, por influência plebeia -, mesmo que à custa do controle do poder político efetivo e a expensas da criação de um mundo democrático-burguês à sua imagem e semelhança. Assim, enquanto a burguesia se encarregou de desenvolver a estrutura econômica, abandonou o estado a um governo de estilo bonapartista, que subordinava a própria burguesia, embora atuando em prol dos seus interesses históricos. Esta via prussiana de objetivação do capitalismo, mesmo largando atrasada, conseguiu, a seu modo, sucesso: em menos de três décadas o país conheceu um crescimento tão grande que o colocou entre os mais desenvolvidos em nível mundial, logrando um desenvolvimento industrial rápido e completo e forcejando, 
via guerra, seu ingresso no rol dos imperialistas. O descolamento entre política e estrutura econômica suscitou ideologias que vinham legitimar intelectualmente essa contradição, apontando-a como uma forma mais alta de desenvolvimento, típica da cultura alemã, contra a vulgaridade da civilização ocidental com que lutava pelo domínio imperialista. Nesse mister, enalteciam a guerra e pleiteavam do estado o controle dos elementos cegos da economia, já que ali o aprofundamento do desenvolvimento capitalista se dissociava do progresso social.

A Alemanha dos séculos XIX e XX é, por essas suas particularidades, caracterizada por Lukács como o país clássico do irracionalismo, onde este se desenvolveu das formas mais variadas e extensas. No quadro de uma ampla crise e no pessimismo de um continente recém-saído de uma guerra imperialista destrutiva, surgiram teorias da história ambiciosas e preditivas, que vaticinavam para breve a chegada de uma sorte de apocalipse político, elas próprias sintomas da crise: "A filosofia da história é o avesso do prognóstico revolucionário." (KOSELLECK apud SILVA, 2008, p. 13) Spengler foi o mais bem-acabado representante dessa tendência, motivo pelo qual é, aqui, tomado como ponto de referência. Assim, a concepção spengleriana, segundo Lukács, tinha caráter consolador, ao pretender que a história é cíclica e que os círculos culturais sempre passaram por perigos semelhantes aos do presente, mas que, ao mesmo tempo, "cada cultura murió de su muerte 'natural', causada por el agotamiento de la vejez, por el anquilosamiento de la civilización" (LUKÁCS, 1972, p. 382). Era um pensamento reconfortante diante do espectro da revolução comunista com que se defrontavam, de um lado, e do capitalismo financeirizado, de outro.

Já Golbery do Couto e Silva, situado no Brasil, tinha tarefas ainda mais complexas de que dar cabo. Sinteticamente, o país objetivou o capitalismo industrial híper-tardiamente ${ }^{13}$, mesmo em relação aos países tardios. Sua burguesia, como a alemã do século XIX, não foi capaz de realizar suas tarefas políticas - liberalismo, direitos humanos e do cidadão, democracia -, conciliando com os representantes da economia agroexportadora, com os quais compartilhavam origens - e excluindo a participação das massas trabalhadoras e populares dos processos decisórios e do desfrute dos produtos de uma nova era histórica. A classe dominante brasileira, fraca e conciliadora, nunca foi autônoma, subordinando-se à dos antigos países metropolitanos e, posteriormente, à estadunidense, sendo, portanto, caudatária, incapaz, por iniciativa e força próprias, de reagir à dominação imperialista. Manteve, por isso, uma

${ }_{13}$ Um debate seminal e percursor sobre as semelhanças e disparidades entre os caminhos alemão e brasileiro de objetivação do capitalismo, ao qual remetemos os interessados, está disponível neste número de Verinotio (cf. CHASIN, 2019, pp. 131-65). 
férrea dominação sobre as classes subordinadas, a qual lhe permitiu inclusive perpetuar uma superexploração de sua força de trabalho impensável em outros lugares. Mas esta burguesia não pôde cumprir nem mesmo seu papel econômico, cabendo ao estado fornecer, direta e indiretamente, as condições básicas para o arranque do processo de industrialização. Formou-se, por conseguinte, um capitalismo atrófico, que nunca poderia ser igual ao seu congênere europeu.

Como não poderia deixar de ser, sugiram aqui também ideologias legitimadoras desse estado de coisas, as quais, mesmo contendo diferenças entre si, são comumente agrupadas sob a designação de pensamento conservador. Reunindo autores como Oliveira Vianna, Alberto Torres, Azevedo Amaral, Plínio Salgado, Gustavo Barroso e Gilberto Freyre, entre outros, este tratou de refletir sobre a incapacidade das classes proprietárias de pôr-se acima de seus interesses mesquinhos, a fim de impulsionar a nação, e propôs-se a formar as elites nacionais. Também analisou, de seu viés ideológico, a especificidade da formação nacional, identificando uma inadequação ao liberalismo, o qual deveria ser superado nos moldes em que existia no mundo ocidental. Sem jamais pôr em tela a superação de nossa miséria por uma democracia do trabalho, propugnava uma interpenetração entre os valores da modernidade ocidental e aqueles da nossa tradição histórica, numa verdadeira revolução conservadora.

É no interior desse debate que se imiscui o autor em análise neste artigo. Sua proposta era realizar as empreitadas econômicas abandonadas pela burguesia nacional, histórica e estruturalmente débil para impor sua autonomia e cumprir suas tarefas históricas, o que acabava encobrindo e justificando a subsunção ao capital internacional. Sua pregação por um regime que realizasse uma acumulação de capital, distribuísse renda criada e ainda preservasse as liberdades públicas - com todos os limites e contradições aí contidas - mostrava-se inviável para o capital atrófico. É onde entrava a ilusão de uma modernização conservadora pleiteada em clara associação com os interesses multinacionais, mas alardeada e pretendida como importante fator para a soberania nacional e, portanto, uma das afiançadoras da segurança nacional e do projeto de construção do Brasil-potência. Este, embora tenha resultado numa complexificação da estrutura econômica nacional, só o fez à custa da reiteração e aprofundamento das mazelas da miséria brasileira. 


\section{Referências bibliográficas}

ABBAGNANO, Nicola. Cultura; Civilização. In: Dicionário de filosofia. São Paulo: Martins Fontes, 2007.

ASSUNÇÃO, Vânia Noeli Ferreira de. O satânico Dr. Go: a ideologia bonapartista de Golbery do Couto e Silva. Dissertação (Mestrado) apresentada à Pontifícia Universidade Católica de São Paulo, São Paulo, 1999.

BARROS, José D'Assunção. Arnold Toynbee e a história comparada das civilizações. Biblos, Rio Grande, 23 (1): 219-29, 2009.

BIRKNER, Walter Marcos Knaesel. O realismo de Golbery. Itajaí: Univali, 2002.

CARLI, Ranieri. Ética, moral e ordem: a crítica de Nietzsche e Durkheim ao sujeito ético. Campinas: Papel Social, 2017.

CARVALHO, Thiago Bonfada de. Geopolítica brasileira e relações internacionais nos anos 50: o pensamento do general Golbery do Couto e Silva. Brasília, Fundação Alexandre de Gusmão, 2010.

CHASIN, J. A miséria brasileira 1964-1994: do golpe militar à crise social. São Paulo: Ad Hominem, 2000.

COVRE, Maria de L. Manzini. A fala dos homens: análise do pensamento tecnocrático 64-81. São Paulo: Brasiliense,1983.

DURKHEIM, Émile. "Solidariedade mecânica", "Solidariedade orgânica", "Preponderância progressiva da solidariedade orgânica". In: RODRIGUES, José. A. (Org.) Durkheim: sociologia. S. Paulo: Ática, 2007. FERREIRA, Oliveiros. A Geopolítica do Brasil revisitada. Revista Política e Estratégia, São Paulo, Convívio, v. II, n. 4, 1984.

GASPARI, Elio. A ditadura derrotada. São Paulo: Cia das Letras, 2003. GOMES, Augusto Patrini Menna Barreto. O conceito de história em Oswald Spengler. Dissertação (Mestrado) apresentada à Faculdade de Filosofia, Letras e Ciências Humanas da Universidade de São Paulo, São Paulo, 2013.

HERF, Jeffrey. O modernismo reacionário: tecnologia, cultura e política na República de Weimar e no Terceiro Reich. São Paulo: Ensaio, 1993.

LUKÁCS, G. Introducción; I; 2.1; 4.4. In: El asalto a razón. 3. ed. Grijalbo: Barcelona/México, 1972.

LUZÓN, José L. El concepto de desarrollo en Arnold J. Toynbee. RDE Revista de Desenvolvimento Econômico, Salvador, BA, ano III, n. 4, pp. 49-6o, jul. 2001.

MELLO, Leonel I. A. Golbery revisitado: da democracia tutelada à abertura controlada. In: MOISÉS, J. A.; ALBUQUERQUE. Dilemas da consolidação da democracia. Rio de Janeiro: Paz e Terra, 1989. 
A Geopolítica do Brasil e a Bacia do Prata. Manaus: Ed. da Universidade da Amazônia, 1997.

NASCIMENTO, Luiz H. F. do. O Ocidente como ideal, propósito e programa: a ESG e a geopolítica do brasil de Golbery do Couto e Silva. Dissertação (mestrado) apresentada à Universidade Federal do Rio Grande do Norte, Natal, 2016.

SCHILLING, Paulo. O expansionismo brasileiro: a geopolítica do general Golbery e a diplomacia do Itamaraty. São Paulo: Global, 1981.

SPENGLER, Oswald. Introdução. In: A decadência do Ocidente. 2. ed. Rio de Janeiro: Zahar, 1973.

SILVA, Golbery do Couto e. Conjuntura política nacional: o poder executivo \& Geopolítica do Brasil. Rio de Janeiro: José Olympio, 1981a. . Planejamento estratégico. Rio de Janeiro: José Olympio, $1981 \mathrm{~b}$.

SILVA, Leandro Assunção da. A ideia de ocidente em Oswald Spengler. Dissertação (Mestrado) apresentada à Universidade Federal do Rio Grande do Norte, Natal, 2008.

Como citar:

ASSUNÇÃO, Vânia Noeli Ferreira de. Ocidente e história em Golbery do Couto e Silva. Verinotio - Revista on-line de Filosofia e Ciências Humanas, Rio das Ostras, v. 25, n. 2, pp. 392-443, nov. 2019.

Data do envio: 1 set. 2019 Data do aceite: 31 out. 2019 